Article

\title{
Multiple-Use Zoning Model for Private Forest Owners in Agricultural Landscapes: A Case Study
}

\section{Benoit Truax ${ }^{1, *}$, Daniel Gagnon ${ }^{1,2}$, France Lambert ${ }^{1}$ and Julien Fortier ${ }^{1}$}

1 Fiducie de recherche sur la forêt des Cantons-de-l'Est/Eastern Townships Forest Research Trust, 1 rue Principale, St-Benoît-du-Lac, QC J0B 2M0, Canada;

E-Mails: daniel.gagnon@uregina.ca (D.G.); france.lambert@frfce.qc.ca (F.L.); fortier.ju@gmail.com (J.F.)

2 Department of Biology, University of Regina, 3737 Wascana Parkway, Regina, SK S4S 0A2, Canada

* Author to whom correspondence should be addressed; E-Mail: btruax @ frfce.qc.ca; Tel.: +1-819-821-8377.

Academic Editor: Damian C. Adams

Received: 10 July 2015 / Accepted: 29 September 2015 / Published: 14 October 2015

\begin{abstract}
Many small-scale private forest owners increasingly focus their management on amenity functions rather than on wood production functions. This paradigm shift is an opportunity to implement novel forestry management approaches, such as forested land zoning. Forest zoning consists in separating the land base in three zones that have different management objectives: (1) conservation zones; (2) ecosystem management zones; and (3) intensive production zones, which locally increase productivity, as a trade off to increase the land area dedicated to conservation and ecosystem management. We evaluate the ecological feasibility of implementing forest zoning on a private property (216 ha) at St-Benoît-du-Lac, Québec (Canada) characterised by agricultural and forest land uses. As a basis for delineating conservation and ecosystem management zones, historical and contemporary data and facts on forest composition and dynamics were reviewed, followed by a detailed forest vegetation analysis of forest communities. Delineating intensive production zones was straightforward, as fertile agricultural field margins located downslope were used to establish multifunctional hybrid poplar buffers. At St-Benoît-du-Lac, a realistic zoning scenario would consist of (1) conservation zones covering $25 \%$ of the forestland ( $37 \mathrm{ha}$ ); (2) ecosystem management zones covering $75 \%$ of the forestland (113 ha, including restoration zones on $24 \mathrm{ha}$ ); and (3) intensive production zones on $2.8 \mathrm{ha}$. Based on a yield projection of $13 \mathrm{t} / \mathrm{ha} / \mathrm{year}$ for hybrid
\end{abstract}


poplars, only $5.6 \%$ of agricultural field areas would need to be converted into agroforestry systems to allow for the loss of wood production in a conservation zone of 37 ha of forest. Ecosystem services provision following the implementation of zoning would include increased habitat quality, biodiversity protection and enhancement (by restoration of some tree species), carbon storage, non-point source aquatic pollution control, local biomass production for heating, and increased forest economic value.

Keywords: ecosystem services; forest conservation and restoration; forest ecosystem management; land use; priority areas; hybrid poplar bioenergy buffer; agroforestry; enrichment and under planting; Quercus; Juglans

\section{Introduction}

Over the last few decades, many temperate rural landscapes, located near urban centers, have been subjected to important land use changes and population migration. Intensive agricultural activities have been concentrated on higher quality soils, and more marginal sites, often located on hilly and/or stony terrain, have been abandoned, a trend sometimes exacerbated by the creation of new regional economic opportunities [1-4]. In many rural localities, urban sprawl has also increased at the expense of forestland and farmland [5]. In the meantime, newcomers from the cities have acquired significant portions of the agricultural and forested land base, which was traditionally managed by long-time residents who were economically dependent on forest exploitation and farming [6,7].

Today, many small-scale private forest owners increasingly focus their management on amenity functions rather than on wood production functions [6,8]. This shift from production activities to multifunctional land use has also been observed in many farmland settings $[9,10]$, resulting in new socioeconomic dynamics that have brought together people with often conflicting views of regional resource management [7]. The confrontation of these different perceptions has contributed to reshaping natural resource management and land use allocation in rural landscapes subjected to amenity migration from urban centers [7,9]. However, there are many issues related to forest conservation and exploitation, but also related to food production systems and their impact on the environment and human health that remain unresolved in these evolving landscapes.

During the last decades, the southern Québec region (Canada), has seen the aforementioned social and ecological transformations of its rural landscapes [4,11-13], and a gradual gentrification of different parts of its countryside is occurring [7]. Consequently, the environmental, recreational and aesthetic qualities of southern Québec landscapes are values gaining importance among rural communities, but also among the general public [14].

An important characteristic of southern Québec, is that most of the land base is in private ownership [15]. The deciduous and mixed forestland of the region is owned by approximately 50,000 landowners, with the large majority of these owning woodlots of 100 ha or less [16]. These woodlots are mainly managed for multiple complementary activities, and motivations to own forest include nature and management enjoyment, timber and non woody forest products harvesting, maple syrup production, recreational activities, complementary source of revenues, long-term investment, and family 
inheritance [16]. This clearly illustrates the paradigm shift from wood production oriented to multi-services oriented management in privately owned forests of southern Québec.

Less than 5\% of southern Québec's area is designated as protected despite the fact that its ecosystems are the most biodiversity rich of the province [17]. Consequently, within the provincial network of protected areas, the deciduous and mixed forest ecosystems of the St. Lawrence Lowlands and the Appalachian ecoregions are still greatly underrepresented, especially on private land [17]. There is a need to establish new conservation zones and corridors on those private lands, despite the small size of most individual properties. Small protected areas ( $<50 \mathrm{ha}$ ) located in human-disturbed temperate landscapes can be important for some taxa (vascular plants, birds, beetles, etc.) and should be established to complement larger protected areas [18]. This is because very small forest patches can contain several key attributes supporting biodiversity, such as coarse woody debris and large trees [18]. Forest conservation also allows forests to age, which is a process strongly related to carbon (C) and nitrogen (N) stock increases in both biomass and soil [19-21]. Thus, forest conservation can contribute to global warming mitigation, but also to greater nutrient retention within watersheds.

The southern Québec region also faces challenges related to water quality management. Non-point source pollution of groundwater, streams and lakes in agricultural areas has contributed to water quality deterioration, habitat degradation, cyanobacteria blooms, biodiversity declines and loss of traditional uses in different localities (drinking water source, sport fisheries, swimming, etc.) [22-25]. All of southern Québec watersheds have recently received a high to very high conservation priority because they support diverse fish communities and very productive aquatic environments, while being at risk from anthropogenic stressors [26].

In the more forested landscapes of southern Québec, increasing afforestation of farmland has been observed over the last decades, which may improve their ecological value [4]. Yet many of those forest-dominated landscapes have been subjected to a severe degradation of their forest resources, as a result of an unsustainable past exploitation of the most valuable tree species (pines, oaks, sugar maple, yellow birch, and beech), which started more than 200 years ago [27]. Today, high quality stems of several hardwoods and pines are scarce, with the Québec wood transformation industry being highly dependent on importation from the United States [28,29]. However, with its large land area of degraded forest and regenerating abandoned farmland, southern Québec has a high potential for forest restoration. A few projects have identified key environmental variables and silvicultural methods that improve the artificial regeneration of locally important species [30-33]. Hardwood enrichment planting in early-successional stands has been identified as a promising low input strategy to restore high value species such as oaks $[31,34]$, with the advantage of requiring no socially controversial conversion of cultivated land into plantations [35].

Environmental problems related to agricultural land cover in southern Québec may also be exacerbated by climate change. For example, anticipated increases in the frequency and intensity of extreme rainfall events during summer could increase agricultural non-point source aquatic pollution and reduce water quality in rural areas [22]. Therefore, the climate change perspective should stimulate communities to lower their $\mathrm{C}$ footprint and increase farmland $\mathrm{C}$ storage capacity, while favouring multi-functionality. One possible avenue would be the substitution of fossil fuels, for heating farm buildings, houses and greenhouses, with renewable woody biomass [36,37] produced in field edge and riparian buffer strips planted with fast-growing trees [38-40]. Regional studies suggest that those systems often require few 
inputs to produce high yields, while contributing to $\mathrm{C}$ storage, non-point source stream pollution abatement and habitat creation [41-44]. Abandoned farmland with sufficient fertility could also be used to intensively produce woody biomass with fast-growing plantations [45].

Within the particular environmental and socioeconomic context of southern Québec, land planners and landowners have an increasing responsibility to implement sustainable farming and forestry, in order to minimise the impacts of food and wood production systems on air, soil, water and visual quality, as well as on biodiversity. This situation poses a serious challenge to policy makers because they have to guide landscape evolution for the benefit of both producers and consumers [12]. Recently, the Québec government has legislated that an ecosystem-based forest management approach will be used on public and private lands [46]. Increasingly, ecological issues will be included in forest management plans [47,48]. Such policy and management changes will contribute to the increase of ecosystem services provided by forests. However, how can land use management and allocation reconcile food and energy production, forest exploitation and conservation simultaneously for the benefit of all users?

In this case study, we suggest that the implementation of a forest zoning management strategy on private land could increase land multi-functionality and provision of ecosystem services. Theoretically, the forest zoning approach aims at maintaining wood production flow, while reducing harvest pressure on the land base, in order to meet non-timber objectives and reduce user conflicts [49-51]. The implementation of this approach often consists in separating the land base in (1) forest conservation zones; (2) extensive or ecosystem-based forest management zones; and (3) intensive production zones, in natural stands and plantation systems. Practically, intensive management zones are used to locally increase forest productivity, and provide the "wood production compensation" needed to increase the land base area dedicated to conservation and ecosystem management.

Forest zoning management scenarios have been implemented on vast forest areas managed by industrials [49,52,53]. However, the application of this concept to smaller private properties (in temperate regions) does not appear in the scientific literature. Many European countries have spatially delimited priority areas of various sizes on private forestland (natural hazard protection, nature conservation, recreation, welfare and production priority areas) in order to improve landscape multi-functionality and meet overlapping societal demands [54]. However, such an approach rarely integrates multiple priority areas at the single property level, or group of adjacent properties, which can result in loss of economic benefits for landowners, because of the non-valuation of non-timber services [54]. In this study, we evaluate the ecological feasibility of implementing forest zoning on a private property (216 ha) owned by the Benedictine monastic community of St-Benoît-du-Lac, Québec (Canada). The proposed zoning scenario integrates: (1) intensive production zones of hybrid poplar buffers (producing biomass for heating monastery buildings) located on the lower slopes of cultivated fields; (2) forest zones dedicated to extensive ecosystem-based forest management and restoration of locally important tree species; and (3) conservation zones that have key ecological attributes and high conservation value. Starting from a well-documented "Base case scenario", we discuss the potential of different forest zoning scenarios to meet objectives related to sustainable forestry, biodiversity conservation, and agriculture and bioenergy production systems, in temperate mixed agricultural and forested landscapes under private ownership. 


\section{Materials and Methods}

The objective of this project was to produce a land-use zoning, on a medium-sized private property. For the intensive production zones, only the areas under agricultural production or recently abandoned fields will be used for the rapid production of wood and/or biomass. The delineation of this zone requires no particular study (easily defined using forest cover maps and/or aerial photos).

However, in the forested parts of the property, we wanted to determine which areas should be allocated to a conservation zone (no harvesting), and which areas could be allocated to an ecosystem-based forest management zone, which could include some harvesting, as well as some restoration plantings, particularly of tree species once much more abundant on the site. To adequately delineate these two types of zones, a detailed analysis of the forest vegetation is a prerequisite. The results obtained will provide all baseline data required to help inform any future conservation actions, as well as any forest management actions. Such data encompass compositional and structural characteristics, site and soil factors, and faunal habitat attributes.

Collecting historical data and facts on regional forest composition and dynamics is also important because ecosystem management should be inspired by historical composition and natural disturbance patterns [50,55]. Such information will then be used to guide forest management operations towards the restoration of forest ecosystem species, attributes and dynamics.

\subsection{Study Site Description}

The study site is located at the St-Benoit-du-Lac Abbey, a 216 ha privately owned property (Benedictine monastery) in the Eastern Townships region of southern Québec, Canada $\left(45^{\circ} 10^{\prime} \mathrm{N}\right.$; $72^{\circ} 16^{\prime} \mathrm{W}$ ) (Figure 1). The land of the Abbey forms an independent municipality with 150 ha of forests, 45 ha of cultivated fields, 5.5 ha of abandoned agricultural fields and apple orchards, 8.5 ha of producing apple orchards, and the Abbey itself (buildings, roads and parking lots) occupies 7 ha. The Benedictine Community acquired this property in 1912, at a period when forest harvesting and agriculture were already well-established activities in this part of the Eastern Townships. Currently, the Abbey buildings are heated with several biomass furnaces, which have replaced an oil furnace.

The study site is located on the western shore of Lake Memphremagog, a large lake $\left(95.3 \mathrm{~km}^{2}\right)$ within a wide north-south valley flanked by hills and a few steep slopes [56] (Figure 1). The Canada-United States border, with the State of Vermont, is located a few kilometers south of the study site (Figure 1). The impact of human activities on forest and agricultural land have contributed to the creation and maintenance of a complex mosaic of young and older successional stands, recently abandoned fields and cultivated fields. Today, the forest cover of the region is dominated mainly by hardwoods on mesic sites and by conifers on xeric and hydric sites, with the study area belonging to the sugar maple-basswood ecoregion [57], which is part of the northern hardwoods forest ecosystem [58,59]. 


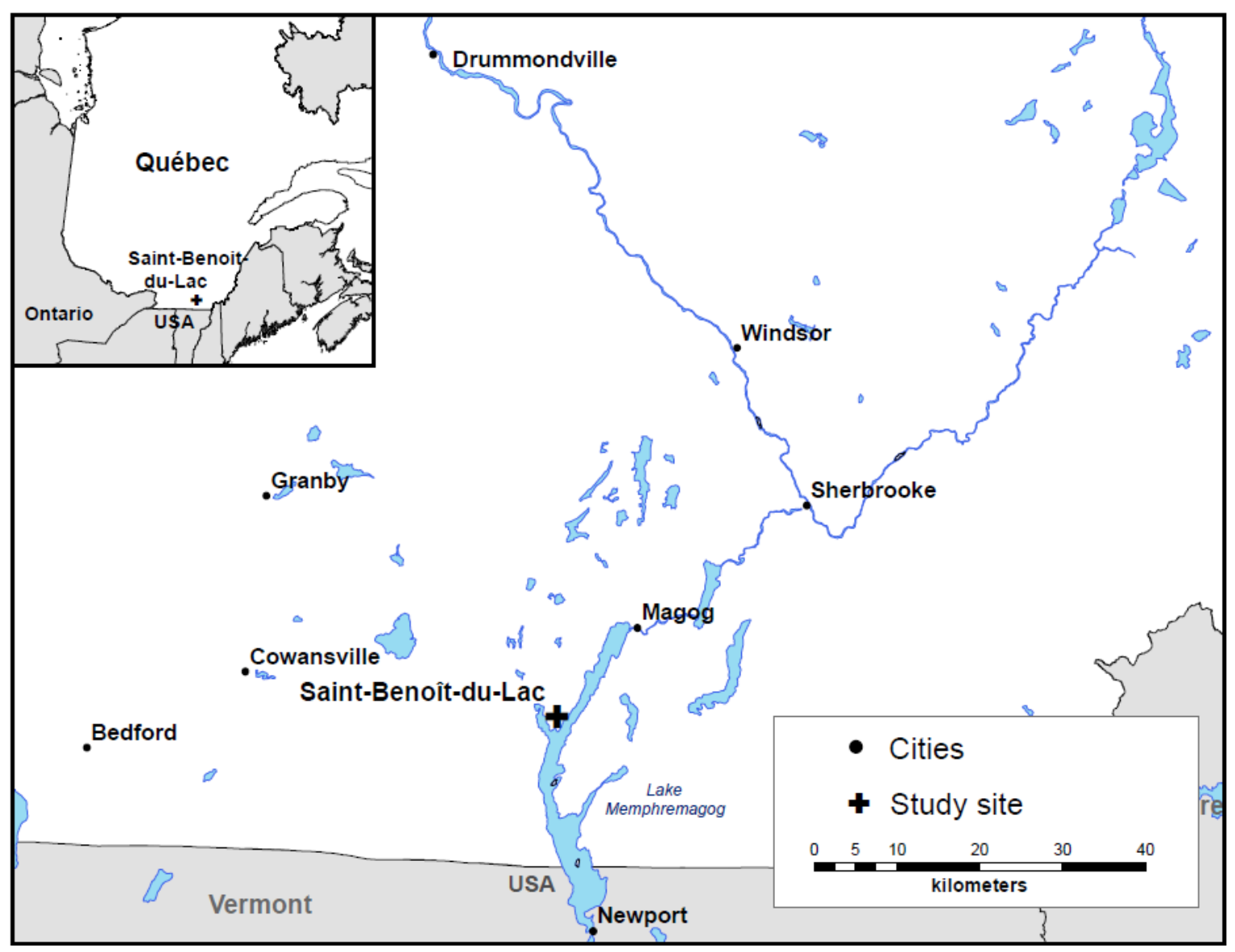

Figure 1. Study site location in the southern Québec region, Canada.

The rock stratum of the area is complex and is generally covered with thick glacial till deposits [57]. The dominant soil sub-groups within the study area are Orthic Dystric Brunisols and, to a lesser extent, Orthic Humic Gleysols of relatively high fertility [60,61]. The region is characterized by a continental moderate-subhumid climate, with a growing season of 180 to 190 days [57]. Climate data indicate that the total annual precipitation is high (over $117.4 \mathrm{~cm}$ ), with an annual mean temperature of $5.6^{\circ} \mathrm{C}$ (mean temperature for January: $-10.4{ }^{\circ} \mathrm{C}$; mean temperature for July: $19.8{ }^{\circ} \mathrm{C}$ ) [31].

\subsection{Natural Disturbance Regime, Historical Forest Composition, Settlement Impacts, and}

\section{Contemporary Stressors Affecting the Northern Hardwoods Forest}

In Maine, (United States), East of the study site, land survey data indicate that severe or catastrophic disturbances (mainly fires and wind throw) were present in pre-settlement forests, but that these events were relatively rare $[62,63]$. The recurrence interval of these large disturbances was long enough to create a forest landscape where approximately $88 \%$ of the forest area was dominated by mid- or late-successional species [62]. Small canopy gaps were the most common form of disturbance [64], with a mean gap size ranging from 24 to $126 \mathrm{~m}^{2}$ (overall mean: $53 \mathrm{~m}^{2}$ ) and a return interval of 75 to 150 years [63]. Tree senescence, pathogens, insect herbivory and storm events (including high winds, heavy snow and ice storms) are likely the main interacting causes creating those small gaps [63]. These small gaps were mostly formed following the death of a single or a few large trees [64], at an average rate of about $1 \%$ of total land area per year [65]. Thus, in north eastern North America, "forests were dominated 
by relatively frequent, partial disturbances that produced a finely patterned, diverse mosaic dominated by late-successional species and structures" [63].

After studying witness tree pre-settlement survey records, Cogbill et al. [59] argued that the northern hardwoods forest of New England was characterised by a single continuous sequence from mixed spruce to pure hardwoods responding to a complex climatic gradient, both latitudinal and altitudinal, with beech (Fagus grandifolia) being by far the most dominant species. More specifically, just south of the study area, near the Québec-Vermont border, upland forests were dominated by beech, followed by spruces, sugar maple, hemlock and yellow birch [59]. Although pines and oaks were probably not dominant species in the region [59], they were probably more abundant than they are today. North eastern North American climax forests were early described as the hemlock-pine-hardwood complex, with species such as red oak being common throughout the ecoregion [64]. Wood sales reported in the notary deeds of the Haut St-Laurent region (130 km west of the study area) suggest that pre-settlement forests on mesic sites were dominated by maple-beech-yellow birch stands [66]. However, beech and yellow birch abundance showed a marked decline following European settlement, while an increase was observed for sugar maple and ash species [66]. Pines and oaks (mostly white pine and bur oak) used for construction of British ships were the first species to be overexploited by European settlers in the Haut St-Laurent, and they were already depleted by the end of the 1840s [27].

In the Eastern Townships region, settlers who mostly got established from 1790 to 1850 were known to be hostile to the forest, which resulted in a severe over-clearing of the land and a wasteful use of the resource [67]. Prior to railroad construction, tree burning accompanied land clearing for agriculture, as markets for timber were inaccessible [67]. Ashes from burned trees were used to produce potash, that was then exported to Britain, becoming the first economic activity in the region [67]. During winter, settlers even burned land unwanted for cultivation, only to produce ashes, while fuelwood for local use was also derived from land clearing [67]. Forest clearance for agriculture mainly occurred on slopes dominated by hardwoods, while lowlands dominated by conifers were left as farm woodlots [67]. At the time, there was a popular rule of thumb correlation between butternut (Juglans cinerea) presence on slopes, and the most highly valued soils for farming [67], with the centre of the Eastern Townships being depicted as the pine, tamarack and butternut kingdom [68]. This strongly suggests that butternut was likely important in the study area, but that it was probably extirpated early. The scale and speed at which land conversion occurred was devastating for forests. In the Stanstead Township, just east of the study area, $62 \%$ of the land area had been cleared by 1881, and put to cultivation or pasture, after which land abandonment began [67].

In the Magog area (study site location), it is only around 1860 that large scale exploitation of the forest resource for sawlog exportation to the United States began [68], with the pioneer sawlog industry being first developed around softwoods [67]. White pine, followed by spruce and red pine were the most valued species, while hemlock and tamarack were not widely used [67]. After felling, logs were dropped in Lake Memphremagog, or in the Cherry River, where they could be easily transported along two key exportation routes. Logs were either transported on timber-rafts on Lake Memphremagog southward to Newport (VT, USA), or they were log driven northward down the Magog River in order to supply the Sherbrooke sawlog industry, which could further supply the United States market through the Sherbrooke to Portland (ME, USA) railroad connection [68] (Figure 1). Timber was also directly transformed at the Magog sawmills (north end of Lake Memphremagog) and sent to United States on 
boats crossing the lake [68]. This local production reached 2,000,000 footboard measures (FBM) in 1870 [68]. By 1890 there was an important stock shortage in the sawlog industry located in the Eastern Townships piedmont [68]. However, despite the over-exploitation and over-clearing of forests that occurred in the 19th century, observations made before 1935 by Frère Marie-Victorin still suggest that three oak species (Quercus rubra, Q. macrocarpa, Q. alba) could be found in the Lake Memphremagog area, as well as bitternut hickory (Carya cordiformis) [69]. Forest exploitation has continued at St-Benoit-du-Lac, following acquisition by the monks in 1912, and it is only by the beginning of 1970s that most of the agricultural land abandonment began on the study site [31].

Other important ecological and human factors might have contributed to modify northern hardwoods forest dynamics and composition, and likely still do. The human control of forest fires in the region may have decreased the populations of oak species, since they are largely regenerated following forest fires [70]. Similarly, white pine is more abundantly regenerated following fire than clear cutting [71]. The natural regeneration of many important local tree species may also be threatened by the increasing impact of white-tailed deer (Odocoileus virginianus) browsing. In 2008, deer populations had already reached 10 individuals $/ \mathrm{km}^{2}$ in the study area [72], with deer densities greater than $9 / \mathrm{km}^{2}$ considered incompatible with the regeneration of various stands [73]. This situation is particularly dramatic for eastern white cedar (Thuja occidentalis), a slow-growing species that is a favourite winter food of deer [74,75]. Severe deer browsing of cedar regeneration has been observed in all cedar stands of the study site (B. Truax, personal observation). There are also indications that old white cedar swamps used to be more common in southern Québec, as they historically formed stable stands where cedar could dominate for several centuries [76].

Additionally, the global commercial exchanges context has brought exotic pests and pathogens to the forests of the region. Very few nut/acorn producing tree species naturally grow in the hilly landscapes of southern Québec, and butternut (Juglans cinerea) is one of these. However, in 2003, the Committee on the Status of Endangered Wildlife in Canada (COSEWIC) recommended that butternut be designated as an endangered species because it is in severe decline, due to high mortality caused by the butternut canker (Sirococcus clavigignenti-juglandacearum), a virulent and deadly Asian fungal pathogen [77]. A recent regional study on the health status of butternut suggested that this species is in sharp decline in all of its habitats [78]. A few butternut trees are present on the study site, but the majority of stems are either infected by the canker, dying or already dead.

Climate changes might also result in important alterations of the disturbance regime that drives northern hardwoods forest ecosystem dynamics, thereby modifying its structure, composition and biogeography [79]. Additionally, climate change may favour the northward migration of native and exotic pathogens and pests [80]. Such interacting changes could create completely new forest dynamics, leading to long-term structural and compositional changes [80,81]. However, the future ecological conditions are difficult to predict, which in turn complicates our capacity to adapt silvicultural prescriptions to this new reality. For example, drought seasonality, intensity and duration cannot be predicted with actual weather models in the northern hardwoods forests of Eastern North America [82]. Nevertheless, at a small-scale, several silvicultural strategies may be used to reduce the vulnerability of forests to global change or to enhance recovery from disturbances. These include changing or adjusting species composition by planting alternative species, altering structure by favouring advanced 
regeneration or by planting late-successional species, and reducing the impact of environmental stresses to speed up post-disturbance recovery [80].

\subsection{Forest Vegetation Analysis}

\subsubsection{Data Collection for Forest Vegetation Analysis}

Forest vegetation analysis work began in 2010 with the study of digital topographical and ecoforest maps, as well as aerial photos (orthophotos) of the site. Using these sources of information and ArcGIS, we established a sampling design for the forested areas. A set of parallel transects were used to determine the location of $20 \mathrm{~m} \times 20 \mathrm{~m}\left(400 \mathrm{~m}^{2}\right)$ sample plots. Efforts were made to distribute sample plots as systematically as possible. A total of 71 permanent plots were sampled in summer 2010. In order to facilitate future precise relocation, all plots have a GPS location, and four trees (near the four corners of the plots) were tagged with numbered metal tags, and their species and DBH were recorded.

Within each sampled plot, all live tree stems larger than $1 \mathrm{~cm}$ diameter at breast height (DBH) were identified to species, counted and their diameter measured. Tree seedlings, measuring from 20 to $130 \mathrm{~cm}$ in height, were counted by species over the entire plot. Tree stems were grouped into several DBH classes: 1-5 cm (small saplings); 5-10 cm (large saplings); 10-20 cm (small trees); > $20 \mathrm{~cm}$ (large trees). A list of understory plant species (herbaceous and small shrubs) was made and a percent coverage value was estimated for each species.

Site ecological data were recorded for each plot: elevation, percent slope and orientation, topographical situation, percent cover of rocks on the forest floor, soil drainage class. Average tree canopy height was estimated using a clinometer. Four sub-samples of soil were taken per plot, and made into a composite sample. Soil samples were collected from 5 to $10 \mathrm{~cm}$ depth in the first mineral horizon (underneath the LFH). Samples were air-dried and then sieved (2 $\mathrm{mm}$ mesh). Samples were sent to the Agri-Direct Lab (Longueuil, QC, Canada) and to the Centre d'étude de la forêt soil lab (Université de Sherbrooke, Québec) for analyses of $\mathrm{pH}$, major cations ( $\mathrm{Ca}, \mathrm{Mg}, \mathrm{K}$ ), cation exchange capacity (CEC), total $\mathrm{C}$ and $\mathrm{N}$ content, available $\mathrm{P}$, as well as percent organic matter content. See Truax et al. [83] and Fortier et al. [84] for a complete description of the methods used for soil analyses.

In order to determine stand age of sampled plots, two to three increment cores were taken from the largest trees (likely to be the oldest). Cored species were selected by a specific order of preference (hemlock, sugar maple, white ash, beech, cedar, etc.), in order to obtain more data for a smaller set of important species. Snags (standing dead trees) were sampled in the same way as live trees, and divided into 3 groups (poplar snags; other hardwood snags; conifer snags). The presence of cut stumps was recorded (last harvest), and fallen trees (coarse woody debris) were recorded (total length of dead wood pieces with a minimum diameter of $20 \mathrm{~cm}$ ). Signs of the presence of fauna were recorded (feces, bones, rubbing on trees, burrows, hollow trees, excavated cavities). 


\subsubsection{Forest Community Determination Using Ordination Analyses}

After the collection of vegetation and ecological data, ordination analyses were done to identify forest community types. These analyses were done using only tree species data. The data matrix was created by dividing each tree species into five pseudo-species: seedlings, small saplings, large saplings, small trees, and large trees. Pseudo-species tree data from 71 sampled plots were analyzed using Detrended Correspondence Analysis (DCA) (Vegan package in the R program [85]). A first ordination allowed us to identify the least typical (or more unique) sampled plots. A second ordination, using only a subset of more typical plots $(n=53)$, allowed us to better discriminate between several forest community types and identify which ecological factors were most strongly associated to their distribution in the study area. Ecological factor data (site and soil variables, stand age, stand structural variables, standing and fallen dead wood) were correlated with the plot scores on ordination axes to identify those factors most strongly associated to forest vegetation variation. In the ordination figures, the strength of the correlations between the ecological factors and the position (coordinates) of vegetation plots on the first two axes are represented by vectors.

Using the two sequential DCA ordinations, we were able to identify 11 forest community types and several unique/atypical plots (Figures 2 and 3). In the first ordination, a group of 4 community types and two plantations, according to the ecological factor vectors, are characterized by younger stand age, high tree stem density (numerous small-sized trees and saplings) and a higher density of hardwood snags (Figure 2). The vegetation patterns in the remaining 53 plots, not identified to community types in the first ordination, can be seen clearly in the second ordination (Figure 3). The second ordination shows 7 forest community types, distributed along a soil drainage gradient along its first axis; poor drainage and flat terrain is prevalent in plots of the white cedar community type, on the positive end of axis 1 , and good drainage and higher percent slope are found in various community types that include sugar maple, on the negative end of axis 1 (Figure 3). The second axis of this ordination shows a stand age and soil $\mathrm{C}: \mathrm{N}$ gradient, with the hemlock — sugar maple-yellow birch community type, on the negative end of the axis, having the oldest trees (one hemlock tree was 255 years old; average stand age was 128 years) and highest soil C:N. These old stands also have the highest total basal area, and occur on sites with the highest soil surface stoniness. At the opposite end of this gradient (positive end of axis 2), a younger sugar maple - white ash community type (average stand age of 81 years) is associated with the higher ground of the study area (higher elevation than other areas), as well as higher soil $\mathrm{P}$ and tree stem density. Finally, there are five plots in the second ordination that were not attributed to any specific community type. 


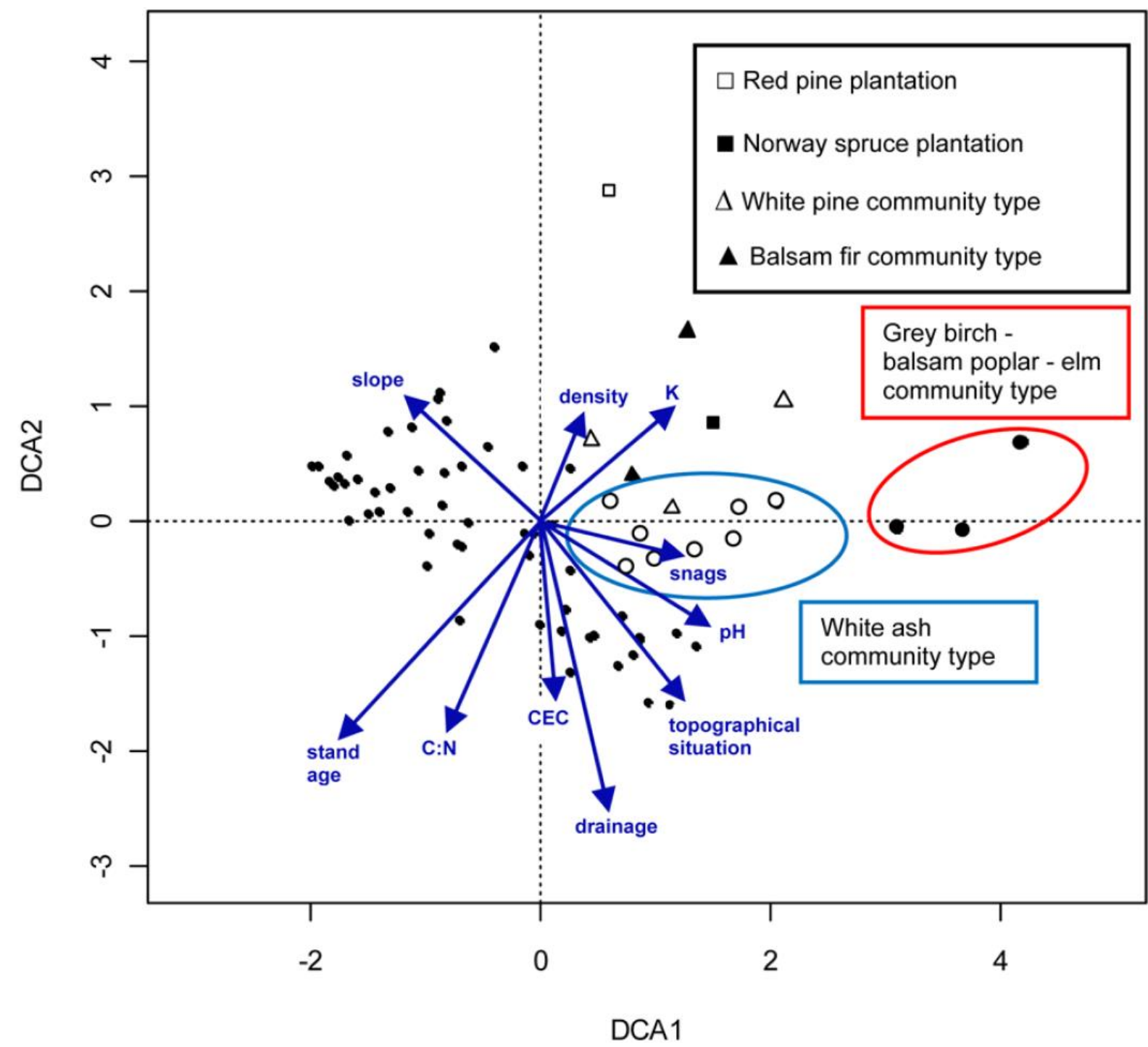

Figure 2. Detrended Correspondence Analysis (DCA) of 71 forest vegetation plots at St-Benoît-du-Lac Abbey. This first ordination helped identify a few atypical or unique plots (red pine plantation, Norway spruce plantation) as well as 4 forest community types that are not common in the study area and/or with younger stand age (total of 18 plots). Ecological factors most strongly correlated with both axes are represented by vectors. Abbreviations: slope $=$ percent slope; density = tree density/ha; $\mathrm{K}=$ soil $\mathrm{K}$; snags = density of hardwood snags; $\mathrm{pH}=$ soil $\mathrm{pH}$; drainage = soil drainage class (rapidly drained to poorly drained); $\mathrm{CEC}=$ soil cation exchange capacity; $\mathrm{C}: \mathrm{N}=$ soil $\mathrm{C}: \mathrm{N}$ ratio; stand age = age of largest trees. 


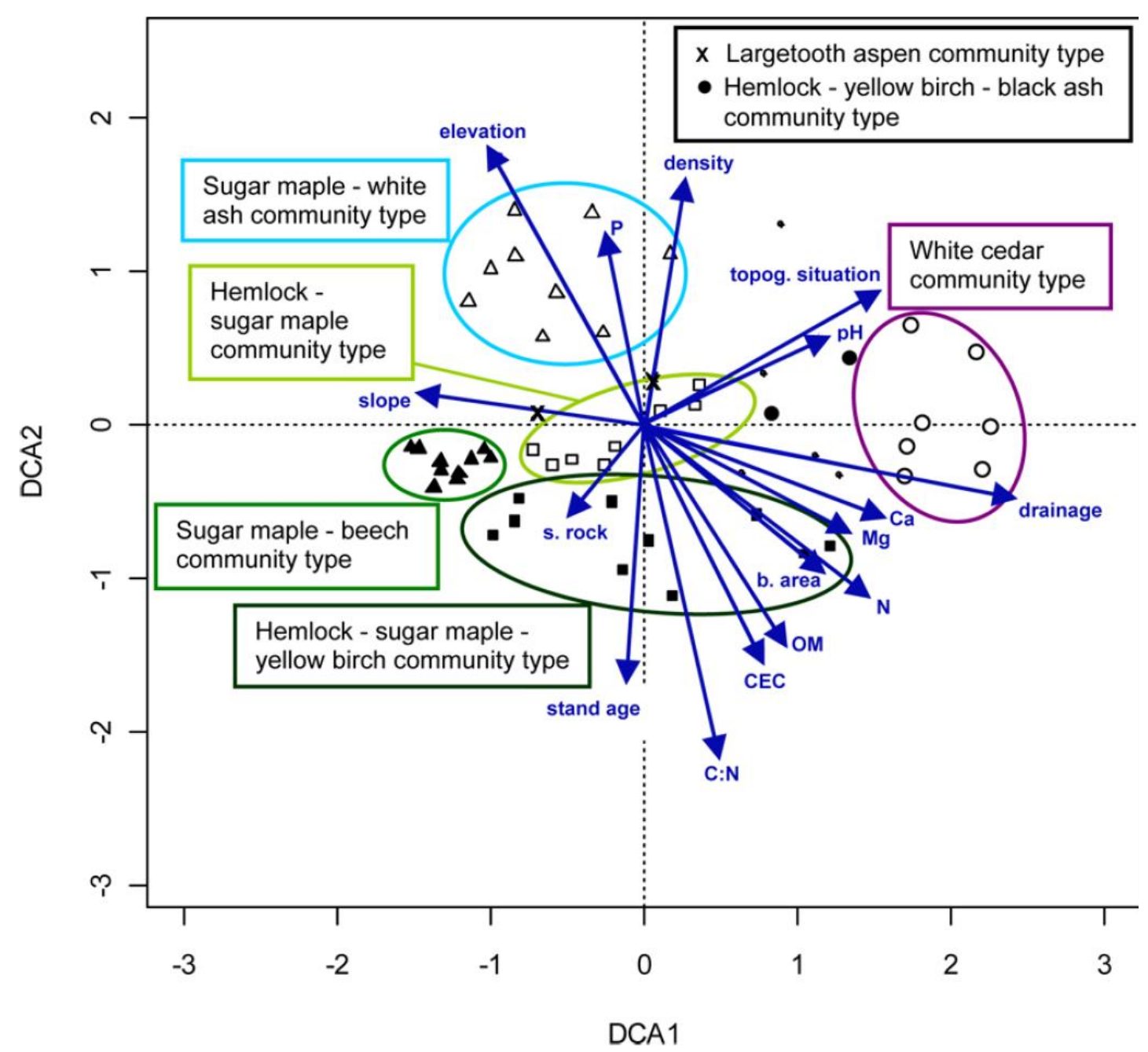

Figure 3. Detrended Correspondence Analysis (DCA) of a subset of 53 forest vegetation plots at St-Benoît-du-Lac Abbey. This second ordination was constructed with data from 53 plots of more typical forest vegetation plots that were not identified in the first ordination. Seven forest community types, that are generally more common in the study area and/or with older stand age, are identified. Five plots were not attributed to any specific community type (represented by small black dots). Ecological factors most strongly correlated with both axes are represented by vectors. Abbreviations: slope = percent slope; elevation = site elevation; $\mathrm{P}=$ soil $\mathrm{P}$; density = tree density/ha; topog. situation = topographical situation; $\mathrm{pH}=$ soil $\mathrm{pH}$; drainage $=$ soil drainage class (rapidly drained to poorly drained) $\mathrm{Ca}=$ soil $\mathrm{Ca} ; \mathrm{Mg}=$ soil $\mathrm{Mg} ; \mathrm{N}=$ soil $\mathrm{N} ; \mathrm{b}$. area = tree basal area/ha; $\mathrm{OM}=$ soil percent organic matter; $\mathrm{CEC}=$ soil cation exchange capacity; $\mathrm{C}: \mathrm{N}=$ soil $\mathrm{C}: \mathrm{N}$ ratio; stand age = age of largest trees; s. rock $=$ percent surface rock cover.

\subsubsection{Young Forests Community Types Description}

The first ordination (Figure 2) has allowed the identification of four of the five forest community types that can be clearly described as young forests, at the origin of which is a major disturbance, such as total harvest (or heavy partial harvest) or abandonment of agriculture (crops or orchard) four to five decades ago. These forest community types are mostly dominated by shade intolerant hardwood species 
(Betula populifolia, B. papyrifera, Populus balsamifera, P. grandidentata, P. tremuloides, F. pennsylvanica, Ulmus americana), and a few hardwood species of intermediate shade tolerance (Betula alleghaniensis, Acer rubrum, Fraxinus americana, Tilia americana) (Table 1). Balsam fir (Abies balsamea), although a shade tolerant species, is abundant as saplings in some of these young forests (Table 1). Among the forest community types in the Young Forests group, only the white pine community type has a mean stand age slightly higher than 60 years (65 years; Table 2 ). One plot of this community type has young planted Norway spruce (Table 1). The relatively low age of the white pines suggests they may have regenerated after a major harvest cut in the past, and that perhaps some were even planted more than 60 years ago.

The young forests have high densities of snags, particularly of hardwood species, including those of large dead poplars (Table 2). Deciduous tree snags, and particularly those of poplars, are preferred by the pileated woodpecker, a keystone species that creates large cavities, which can further be used by other tree nesting species such as flying squirrels $[86,87]$.

The generally flat terrain and relatively rich soils of the white ash community type (with better soil drainage) and of the grey birch — balsam poplar — elm community type (with poorer soil drainage) are factors that made agricultural development advantageous in the past. The low $\mathrm{C}: \mathrm{N}$ ratio of their soils also reflects this agricultural past (Table 3). 
Table 1. Relative density of large saplings (5-10 cm DBH; Sap. in table) and relative basal area of large trees (>20 cm DBH; Trees in table) of the Young Forests community types of the St-Benoit-du-Lac Abbey forested areas. Means of large sapling density, tree (>10 cm DBH) density, large tree basal area, and total basal area (saplings + trees) for each community type are indicated at the bottom of the table. The number of plots in which saplings and trees of each species were recorded is given in brackets in the table.

\begin{tabular}{|c|c|c|c|c|c|c|c|c|c|c|}
\hline \multirow[t]{2}{*}{ Tree Species and Community Structure } & \multicolumn{2}{|c|}{$\begin{array}{c}\text { Grey Birch-Balsam } \\
\text { Poplar-Elm } \\
\text { Y-1 (3 plots) } \\
\end{array}$} & \multicolumn{2}{|c|}{$\begin{array}{l}\text { Balsam Fir } \\
\text { Y-2 (2 plots) }\end{array}$} & \multicolumn{2}{|c|}{$\begin{array}{l}\text { White Ash } \\
\text { Y-3 (8 plots) }\end{array}$} & \multicolumn{2}{|c|}{$\begin{array}{l}\text { Largetooth Aspen } \\
\text { Y-4 (2 plots) }\end{array}$} & \multicolumn{2}{|c|}{$\begin{array}{l}\text { White Pine } \\
\text { Y-5 (3 plots) }\end{array}$} \\
\hline & Sap. & Trees & Sap. & Trees & Sap. & Trees & Sap. & Trees & Sap. & Trees \\
\hline Abies balsamea & & & $48(2)$ & & $13(6)$ & $2(2)$ & $8(1)$ & & $1(1)$ & \\
\hline Acer pensylvanicum & & & & & & & $6(2)$ & & & \\
\hline Acer rubrum & & & $1(1)$ & $54(1)$ & $+(1)$ & & $10(2)$ & & $10(3)$ & $1(1)$ \\
\hline Acer saccharum & & & $1(1)$ & & $8(4)$ & $8(3)$ & $16(2)$ & $7(2)$ & $14(1)$ & $1(1)$ \\
\hline Betula alleghaniensis & & & & & & & $3(2)$ & $17(1)$ & $3(1)$ & \\
\hline Betula papyrifera & $3(1)$ & & $20(2)$ & $10(1)$ & $+(1)$ & $4(2)$ & $3(2)$ & $5(1)$ & & $1(1)$ \\
\hline Betula populifolia & $78(3)$ & & & & $7(5)$ & $1(1)$ & & & $9(1)$ & $4(1)$ \\
\hline Fagus grandifolia & & & & & $+(1)$ & & $26(2)$ & & & \\
\hline Fraxinus americana & & & $13(1)$ & & $43(8)$ & $45(8)$ & $8(2)$ & $1(1)$ & $22(2)$ & \\
\hline Fraxinus nigra & $4(1)$ & & & & $7(2)$ & & & & $4(1)$ & \\
\hline Fraxinus pennsylvanica & & & $2(1)$ & $21(1)$ & $+(1)$ & & & & & \\
\hline Juglans cinerea & & & & & & & & & & $4(1)$ \\
\hline Ostrya virginiana & & & & & $8(5)$ & $1(1)$ & $2(1)$ & & & \\
\hline Picea abies & & & & & & & & & $21(1)$ & \\
\hline Picea glauca & & & $10(1)$ & & & & & & & \\
\hline Pinus strobus & & & & & & & & & $11(3)$ & $89(3)$ \\
\hline Populus balsamifera & $10(2)$ & $67(2)$ & & & & & & & & \\
\hline Populus deltoides & & & & & & $1(1)$ & & & & \\
\hline Populus grandidentata & & & & & $1(1)$ & $7(1)$ & $11(1)$ & $69(2)$ & & \\
\hline Populus tremuloides & & & & $15(1)$ & $3(1)$ & $10(2)$ & & & & \\
\hline Prunus serotina & & & & & $+(1)$ & $1(1)$ & $4(1)$ & & & \\
\hline
\end{tabular}


Table 1. Cont.

\begin{tabular}{|c|c|c|c|c|c|c|c|c|c|c|}
\hline \multirow[t]{2}{*}{ Tree Species and Community Structure } & \multicolumn{2}{|c|}{$\begin{array}{c}\text { Grey Birch-Balsam } \\
\text { Poplar-Elm } \\
\text { Y-1 (3 plots) }\end{array}$} & \multicolumn{2}{|c|}{$\begin{array}{l}\text { Balsam Fir } \\
\text { Y-2 (2 plots) }\end{array}$} & \multicolumn{2}{|c|}{$\begin{array}{l}\text { White Ash } \\
\text { Y-3 (8 plots) }\end{array}$} & \multicolumn{2}{|c|}{$\begin{array}{l}\text { Largetooth Aspen } \\
\text { Y-4 (2 plots) }\end{array}$} & \multicolumn{2}{|c|}{$\begin{array}{l}\text { White Pine } \\
\text { Y-5 (3 plots) }\end{array}$} \\
\hline & Sap. & Trees & Sap. & Trees & Sap. & Trees & Sap. & Trees & Sap. & Trees \\
\hline Thuja occidentalis & & & & & $+(1)$ & & & & & \\
\hline Tilia americana & & & $1(1)$ & & $+(1)$ & $1(1)$ & $1(1)$ & & $4(2)$ & \\
\hline Tsuga canadensis & & & & & & & $1(1)$ & & & \\
\hline Ulmus americana & $4(1)$ & $33(1)$ & $2(1)$ & & $7(8)$ & $18(6)$ & & & $2(1)$ & \\
\hline Mean sapling $(5-10 \mathrm{~cm})$ density $(\mathrm{n} / \mathrm{ha})$ & \multicolumn{2}{|c|}{292} & \multicolumn{2}{|c|}{1,838} & \multicolumn{2}{|c|}{878} & \multicolumn{2}{|c|}{900} & \multicolumn{2}{|c|}{583} \\
\hline Mean tree $(>10 \mathrm{~cm})$ density $(\mathrm{n} / \mathrm{ha})$ & \multicolumn{2}{|c|}{567} & \multicolumn{2}{|c|}{775} & \multicolumn{2}{|c|}{994} & \multicolumn{2}{|c|}{1,000} & \multicolumn{2}{|c|}{717} \\
\hline Mean tree $(>20 \mathrm{~cm})$ basal area $\left(\mathrm{m}^{2} / \mathrm{ha}\right)$ & \multicolumn{2}{|c|}{10} & \multicolumn{2}{|c|}{5} & \multicolumn{2}{|c|}{12} & \multicolumn{2}{|c|}{25} & \multicolumn{2}{|c|}{32} \\
\hline Mean total basal area (saplings + trees $)\left(\mathrm{m}^{2} / \mathrm{ha}\right)$ & \multicolumn{2}{|c|}{18} & \multicolumn{2}{|c|}{46} & \multicolumn{2}{|c|}{30} & \multicolumn{2}{|c|}{40} & \multicolumn{2}{|c|}{43} \\
\hline
\end{tabular}

Table 2. Relative density of large saplings (5-10 cm DBH; Sap. in table) and relative basal area of large trees (>20 cm DBH; Trees in table) of the Old Forests community types of the St-Benoît-du-Lac Abbey forested areas. Means of large sapling density, tree ( $>10 \mathrm{~cm}$ DBH) density, large tree basal area, and total basal area (saplings + trees) for each community type are indicated at the bottom of the table. The number of plots in which saplings and trees of each species were recorded is given in brackets in the table.

\begin{tabular}{|c|c|c|c|c|c|c|c|c|c|c|c|c|}
\hline \multirow[t]{2}{*}{ Tree Species and Community Structure } & \multicolumn{2}{|c|}{$\begin{array}{c}\text { Sugar } \\
\text { Maple-White Ash } \\
\text { O-1 (9 plots) }\end{array}$} & \multicolumn{2}{|c|}{$\begin{array}{c}\text { Sugar } \\
\text { Maple-Beech } \\
\text { O-2 (10 plots })\end{array}$} & \multicolumn{2}{|c|}{$\begin{array}{c}\text { Hemlock-Sugar } \\
\text { Maple } \\
\text { O-3 (8 Plots) }\end{array}$} & \multicolumn{2}{|c|}{$\begin{array}{c}\text { Hemlock-Sugar } \\
\text { Maple-Yellow Birch } \\
\text { O-4 (10 Plots) }\end{array}$} & \multicolumn{2}{|c|}{$\begin{array}{c}\text { Hemlock-Yellow } \\
\text { Birch-Black Ash } \\
\text { O-5 (2 Plots) }\end{array}$} & \multicolumn{2}{|c|}{$\begin{array}{l}\text { White Cedar } \\
\text { O-6 (7 Plots) }\end{array}$} \\
\hline & Sap. & Trees & Sap. & Trees & Sap. & Trees & Sap. & Trees & Sap. & Trees & Sap. & Trees \\
\hline Abies balsamea & $1(1)$ & & & & $8(4)$ & $6(1)$ & $6(6)$ & & $4(2)$ & & $48(7)$ & $7(4)$ \\
\hline Acer pensylvanicum & $5(3)$ & & $24(8)$ & & $6(4)$ & & $21(7)$ & & $1(1)$ & & & \\
\hline Acer rubrum & $6(1)$ & $6(2)$ & $1(2)$ & $5(2)$ & $1(1)$ & $5(2)$ & $3(2)$ & $5(6)$ & $1(1)$ & $8(1)$ & $1(1)$ & $2(1)$ \\
\hline Acer saccharum & $46(9)$ & $53(9)$ & $2(6)$ & $70(10)$ & $9(4)$ & $17(8)$ & $3(2)$ & $15(8)$ & & $11(1)$ & $+(1)$ & \\
\hline Betula alleghaniensis & $+(1)$ & $2(2)$ & $1(2)$ & $6(6)$ & $2(2)$ & $5(4)$ & $11(5)$ & $9(5)$ & $4(2)$ & $23(2)$ & $8(4)$ & $7(4)$ \\
\hline Betula papyrifera & & $5(2)$ & & & & $2(1)$ & $+(1)$ & $+(1)$ & & & $+(1)$ & $1(1)$ \\
\hline
\end{tabular}


Table 2. Cont

\begin{tabular}{|c|c|c|c|c|c|c|c|c|c|c|c|c|}
\hline \multirow[t]{2}{*}{ Tree Species and Community Structure } & \multicolumn{2}{|c|}{$\begin{array}{c}\text { Sugar } \\
\text { Maple-White Ash } \\
\text { O-1 (9 plots) } \\
\end{array}$} & \multicolumn{2}{|c|}{$\begin{array}{c}\text { Sugar } \\
\text { Maple-Beech } \\
\text { O-2 (10 plots })\end{array}$} & \multicolumn{2}{|c|}{$\begin{array}{c}\text { Hemlock-Sugar } \\
\text { Maple } \\
\text { O-3 (8 Plots) } \\
\end{array}$} & \multicolumn{2}{|c|}{$\begin{array}{c}\text { Hemlock-Sugar } \\
\text { Maple-Yellow Birch } \\
\text { O-4 (10 Plots) } \\
\end{array}$} & \multicolumn{2}{|c|}{$\begin{array}{c}\text { Hemlock-Yellow } \\
\text { Birch-Black Ash } \\
\text { O-5 (2 Plots) } \\
\end{array}$} & \multicolumn{2}{|c|}{$\begin{array}{l}\text { White Cedar } \\
\text { O-6 (7 Plots) }\end{array}$} \\
\hline & Sap. & Trees & Sap. & Trees & Sap. & Trees & Sap. & Trees & Sap. & Trees & Sap. & Trees \\
\hline Betula populifolia & & & & & $+(1)$ & $2(1)$ & $1(1)$ & & & & & \\
\hline Fagus grandifolia & $15(7)$ & $9(4)$ & $61(10)$ & $14(7)$ & $39(8)$ & $8(3)$ & $22(8)$ & $9(5)$ & $4(1)$ & & & \\
\hline Fraxinus americana & $8(3)$ & $14(5)$ & $3(6)$ & $3(4)$ & $10(4)$ & $7(3)$ & $1(2)$ & $5(4)$ & $6(2)$ & $13(2)$ & $5(3)$ & $3(2)$ \\
\hline Fraxinus nigra & & & & & $4(2)$ & & $3(2)$ & $+(1)$ & $66(2)$ & $8(1)$ & $23(5)$ & $6(3)$ \\
\hline Juglans cinerea & & $3(1)$ & & & & & & & & & & $4(1)$ \\
\hline Ostrya virginiana & $11(4)$ & & $3(4)$ & & $4(4)$ & $2(2)$ & & & $3(1)$ & & $2(3)$ & $1(1)$ \\
\hline Picea glauca & & & & & $4(1)$ & & $+(1)$ & $1(1)$ & & & & \\
\hline Pinus strobus & & & & & & & & & & & $1(1)$ & $5(1)$ \\
\hline Populus grandidentata & & & $+(1)$ & & $3(1)$ & $2(1)$ & $+(1)$ & & & & $1(1)$ & \\
\hline Prunus pensylvanica & $+(1)$ & $2(1)$ & $4(3)$ & & & & $1(1)$ & & & & & \\
\hline Prunus serotina & $7(3)$ & & $+(1)$ & & $1(3)$ & & $+(1)$ & & $1(1)$ & & & $+(1)$ \\
\hline Thuja occidentalis & & & & & & & $1(1)$ & $2(3)$ & $1(1)$ & & $4(4)$ & $55(7)$ \\
\hline Tilia americana & $+(1)$ & $2(2)$ & & $1(1)$ & $3(2)$ & & $1(1)$ & $+(1)$ & $4(2)$ & & $1(1)$ & $2(1)$ \\
\hline Tsuga canadensis & & $2(2)$ & $1(3)$ & $1(1)$ & $4(2)$ & $43(8)$ & $25(9)$ & $53(10)$ & $3(2)$ & $37(2)$ & $2(3)$ & $6(5)$ \\
\hline Ulmus americana & & & $+(1)$ & & & & & & $1(1)$ & & $3(2)$ & \\
\hline Mean sapling $(5-10 \mathrm{~cm})$ density $(\mathrm{n} / \mathrm{ha})$ & 54 & & & & & & & & $1,($ & & & \\
\hline Mean tree $(>10 \mathrm{~cm})$ density $(\mathrm{n} / \mathrm{ha})$ & 61 & & & & & & & & 1, & & & \\
\hline Mean tree $(>20 \mathrm{~cm})$ basal area $\left(\mathrm{m}^{2} / \mathrm{ha}\right)$ & 23 & & & & & & & & 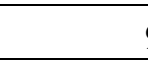 & & & \\
\hline Mean total basal area (saplings + trees) $\left(\mathrm{m}^{2} / \mathrm{ha}\right)$ & 33 & & & & & & & & 3 & & & \\
\hline
\end{tabular}


Table 3. Means of site factors, soil factors, stand age and deadwood (snags and coarse woody debris) abundance for the Young (Y) and Old (O) Forests community types of the St-Benoit-du-Lac Abbey forested areas. Community type codes: Y-1, grey birch-balsam poplar-elm; Y-2, balsam fir; Y-3, white ash; Y-4, largetooth aspen; Y-5, white pine; O-1, maple—white ash; O-2, sugar maple—beech; O-3, hemlock—sugar maple; O-4, hemlock—sugar maple—yellow birch; O-5, hemlock—yellow birch—black ash; O-6, white cedar. Soil factors of agricultural fields used for intensive biomass production are also indicated (Fields).

\begin{tabular}{|c|c|c|c|c|c|c|c|c|c|c|c|c|}
\hline \multirow{2}{*}{ Ecological Factors, Stand Age and Deadwood Abundance } & \multicolumn{12}{|c|}{ Forest Community Types } \\
\hline & Y-1 & Y-2 & Y-3 & Y-4 & $Y-5$ & $0-1$ & O-2 & O-3 & O-4 & $0-5$ & $0-6$ & Fields \\
\hline \multicolumn{13}{|l|}{ Site Factors } \\
\hline Elevation (m) & 227 & 273 & 258 & 238 & 239 & 268 & 248 & 242 & 238 & 239 & 238 & - \\
\hline Slope $(\%)$ & 0 & 1 & 7 & 13 & 16 & 13 & 11 & 14 & 12 & 6 & 3 & - \\
\hline Topographical situation ${ }^{1}$ & 9 & 8.5 & 7.1 & 5.5 & 4.7 & 6.1 & 4.3 & 6 & 5.4 & 3.5 & 8.3 & - \\
\hline Rocks on soil surface $(\%)$ & 12 & 2 & 18 & 15 & 10 & 9 & 15 & 16 & 14 & 27 & 7 & - \\
\hline Soil drainage class ${ }^{2}$ & 3.3 & 3 & 2.5 & 2 & 1.7 & 2 & 2.3 & 2 & 2.7 & 3.5 & 5.4 & - \\
\hline \multicolumn{13}{|l|}{ Soil Factors } \\
\hline $\mathrm{pH}$ (water) & 5.7 & 5.6 & 5.3 & 5.2 & 5.1 & 5.0 & 4.8 & 4.9 & 4.9 & 5.7 & 5.4 & 6.3 \\
\hline CEC (meq/100g) & 27 & 25 & 24 & 18 & 19 & 18 & 23 & 27 & 27 & 29 & 24 & 20 \\
\hline $\mathrm{P}(\mathrm{kg} / \mathrm{ha})$ & 22 & 29 & 18 & 14 & 16 & 58 & 19 & 22 & 19 & 17 & 24 & 98 \\
\hline $\mathrm{Ca}(\mathrm{kg} / \mathrm{ha})$ & 6053 & 4305 & 3495 & 1745 & 2083 & 1746 & 1877 & 3474 & 3408 & 6190 & 4511 & 4903 \\
\hline $\mathrm{K}(\mathrm{kg} / \mathrm{ha})$ & 191 & 134 & 155 & 134 & 117 & 110 & 115 & 121 & 127 & 127 & 114 & 226 \\
\hline $\mathrm{Mg}(\mathrm{kg} / \mathrm{ha})$ & 927 & 891 & 509 & 341 & 278 & 263 & 333 & 493 & 546 & 1198 & 550 & 502 \\
\hline $\mathrm{N}(\mathrm{mg} \mathrm{N} / \mathrm{g})$ & 5.1 & 16.7 & 4.9 & 4.1 & 3.1 & 3.6 & 4.6 & 6.3 & 5.8 & 7.1 & 6.7 & 4.2 \\
\hline $\mathrm{C}: \mathrm{N}$ & 10.9 & 14.7 & 11.4 & 12.4 & 12.6 & 10.8 & 14.3 & 15.5 & 16.6 & 15.4 & 15.3 & 9.6 \\
\hline Organic matter $(\%)$ & 11 & 15 & 14 & 9 & 7 & 7 & 12 & 17 & 17 & 20 & 14 & 8 \\
\hline \multicolumn{13}{|l|}{ Stand Age } \\
\hline Mean age of largest trees & 40 & 43 & 47 & 47 & 65 & 81 & 99 & 115 & 128 & 86 & 97 & - \\
\hline \multicolumn{13}{|l|}{ Deadwood } \\
\hline Fallen deadwood ${ }^{3}$ (m/ha) & 7.5 & 162.5 & 302.5 & 370 & 337.5 & 615 & 327.5 & 447.5 & 580 & 457.5 & 730 & \\
\hline Large snag density ${ }^{4}$ (snags/ha) & 0 & 100 & 31 & 12 & 25 & 22 & 35 & 12 & 32 & 25 & 43 & - \\
\hline Total snag density (snags/ha) & 58 & 137 & 144 & 87 & 25 & 50 & 50 & 19 & 72 & 37 & 136 & - \\
\hline
\end{tabular}

${ }^{1}$ Topographical situation classes 1 to $10: 1$ rounded summit; 2 convex upper slope; 3 concave upper slope; 4 convex mid-slope; 5 concave mid-slope; 6 convex lower slope; 7 concave lower slope; 8 flat convex; 9 flat concave; 10 open depression. ${ }^{2}$ Soil drainage classes 1 to $7: 1$ rapidly drained; 2 well-drained; 3 well to moderately well-drained; 4 moderately drained; 5 moderately to imperfectly drained; 6 imperfectly drained; 7 poorly drained. ${ }^{3}$ Total length of fallen deadwood with a small end diameter $>20 \mathrm{~cm} .{ }^{4}$ Large snags with a DBH $>20 \mathrm{~cm}$. 
Two less frequent community types are the largetooth aspen community type and the balsam fir community type (Table 1). The largetooth aspen stands are located on well-drained sites with moderate slopes (Table 2), which were likely occupied by a sugar maple community type before a clear cut. The strong regeneration (large saplings) by maples, beech and white ash supports this hypothesis (Table 1). The balsam fir community type stands are dominated by large canopy trees of other species, such as red maple, red ash, paper birch and trembling aspen (Table 1). However, it is balsam fir which dominates the understory sapling stratum. The two balsam fir stands are located on very flat sites with rich soils, and contain high densities of hardwood snags (Table 2).

\subsubsection{Old Forests Community Types Description}

On the second ordination (Figure 3), we were able to identify six forest community types that can generally be described as old forests. Some of them have stand origins that are most certainly pre-colonial, such as the hemlock - sugar maple-yellow birch stands. For others, such as the sugar maple - white ash stands (O-1), stand origin is likely to have resulted from relatively minor disturbances, such as partial harvests. The most singular community type of this group of old forests is undoubtedly the white cedar community type (O-6), with site and soil characteristics that are very different from those of other community types. These cedar swamps are located on concave lower slopes or in depressions, and the drainage is imperfect to poor. Also, the soils are particularly rich, and snags and fallen deadwood are abundant (Table 3). Old cedar swamps, with very large white cedars, have become rare in southern Québec, because of the overharvesting of cedar for its rot resistant wood. The two oldest cedars cored were 110 and 124 years old.

The hemlock and sugar maple community types (O-2, O-3, O-4, O-5; Tables 2 and 3) form a group of four old forest community types which correspond fairly well to the pre-colonial forests described by several authors $[59,64,66]$. The site and soil factors vary relatively little among these community types, but the mean stand age does (Table 3). The hemlock—-sugar maple-yellow birch stands (O-4) are definitely the oldest forests of this group, and the oldest in the entire study site. Several indicators support the conclusion that these are old-growth forests of pre-colonial origin, which have never been clear cut (although the possibility of the selective harvest of a few trees in the distant past cannot be ruled out). These stands contain relatively few trees, but they are very large (Table 2), and their soils have a low $\mathrm{pH}$ (4.9) and a C:N ratio that is the highest for the study area (Table 2). Also, historically, hemlock was not widely used in the saw timber industry at the time of settlement in the region [67], which is consistent with the presence of hemlock trees of more than 255 years of age in the hemlock — sugar maple - yellow birch community type (O-4).

The hemlock - sugar maple community type (O-3) stands are very similar to the oldest hemlock community type (O-4), particularly for their soil factors, but they have a younger mean stand age by 13 years (Table 3). We can surmise that stands of this community type where visited more often for selective harvest, perhaps because they occupy more accessible lower slopes, as opposed to mid-slopes (Table 3). The greater abundance of sugar maple, white ash and beech in the hemlock-sugar maple stands, particularly in the large saplings size-class (Table 2), supports this hypothesis.

The sugar maple - beech community type (O-2) stands are the oldest sugar maple dominated stands of the study site, with a mean stand age of 99 years (Table 3). Their soils are in fact slightly more acid 
and poorer in $\mathrm{Ca}$ than those of the hemlock community types, but their soil $\mathrm{C}: \mathrm{N}$ ratio is similar (Table 3). The regeneration in the sugar maple-beech community type is strongly dominated by beech, with $61 \%$ of the large sapling stems (5 to $10 \mathrm{~cm} \mathrm{DBH)} \mathrm{(Table} \mathrm{2).} \mathrm{Sugar} \mathrm{maple} \mathrm{regenerates} \mathrm{poorly}$ (2\% of large saplings). Striped maple (Acer pensylvanicum) is the second most abundant large sapling (24\%), but this small tree never reaches the canopy. It seems like sugar maple-beech stands are transitioning towards beech dominance in the tree size-classes, seen in the pattern of increased dominance by beech in old-growth pre-colonial forests of southern Québec, as described for a 300 year-old pre-colonial forest [88]. This would also be consistent with data from Cogbill et al. [59], showing the absolute domination of beech in the pre-settlement northern hardwoods forests. The sugar maple - white ash community type (O-1) stands have the youngest mean stand age among the old forests (81 years; Table 3). The large tree size-class is dominated by sugar maple and white ash, and sugar maple strongly dominates ( $46 \%$ of stems) the large sapling size-class (Table 2). The abundance of many tree species of intermediate shade tolerance (Fraxinus americana, Tilia americana, Ostrya virginiana) and of black cherry (Prunus serotina) (Table 2) are strong indicators of past disturbances. We hypothesize that these disturbances were likely to have been caused by selective harvests and thinning harvests, within sugar maple forest areas used in part to produce maple syrup.

A less common community type within the old forests group is the hemlock-yellow birch-black ash community type (O-5), the two stands of which are located on mid-slope sites with abundant rocks $(27 \%)$ on the soil surface, with soils with high organic matter content $(20 \%)$ and the highest Ca content of the entire study site (Table 2). It is likely that the shale bedrock is outcropping in these stands.

\subsection{Delineating the Conservation Zone}

The vegetation analyses carried out in the previous section, along with seven conservation criteria, allow us to determine the areas proposed for the conservation zones in the forested areas of the St-Benoît-du-Lac Abbey property. These criteria were: (1) presence of old or exceptional forest communities; (2) occurrence of rare/threatened forest plants; (3) abundance of coarse woody debris (fallen deadwood) on the forest floor; (4) abundance of large snags and cavity trees; (5) presence of a natural stream (aquatic and riparian habitats); (6) presence of a forest corridor connected to adjacent forested properties and to Lake Memphremagog; (7) signs of wildlife activity (feces, burrows, animal tracks).

We propose that priority zones for conservation should include all rare and/or exceptional forest communities, especially those that have species assemblages similar to the northern hardwoods pre-settlement forests (see historical data in Section 2.2). In this respect, the stands of the hemlock-sugar maple-yellow birch community type (O-4), the hemlock - sugar maple community type (O-3), and the sugar maple-beech community type (O-2) must all be protected in the conservation zone. These hemlock and sugar maple-beech community types are old-growth forests, most likely to be of pre-colonial origin, which have become very rare regionally [76]. These community types are dominated by hemlock and beech, two species which have had steep declines in southern Québec during the last two centuries [66]. Also, the old white cedar swamps (O-6) are all to be included in the conservation zone since this wetland habitat has become rare in southern Québec [76]. Most of the stands of the community types aforementioned are located in or near the riparian zone of a small stream that crosses 
the eastern half of the property (Figures 4 and 5). This riparian habitat is very important for species particular to this habitat, and for the natural corridor it represents for wildlife. The old forests community types also contain a high volume of coarse woody debris on the forest floor, as well as numerous large snags (Table 3). All of these attributes increase the conservation value of the area occupied by these forest stands given the importance of deadwood, standing and fallen, and riparian corridors for biodiversity $[18,89,90]$. We will also include as many stands of the white pine community type (Y-5) as possible, because such stands on mesic sites have also greatly declined in southern Québec following overexploitation by settlers [27,67]. These pine stands are also located in or near riparian habitats of the lake and of another small stream (Figure 5), which increases their conservation value. Taking all of these elements into consideration, a first conservation zone of 30 ha is proposed in the eastern forested half of the property, as a relatively large corridor composed of old forests and pine stands, located along the north-south axis of a major permanent stream, which assures the connectivity between forested areas on adjacent properties to the north, and south to Lake Memphremagog (Figure 4).

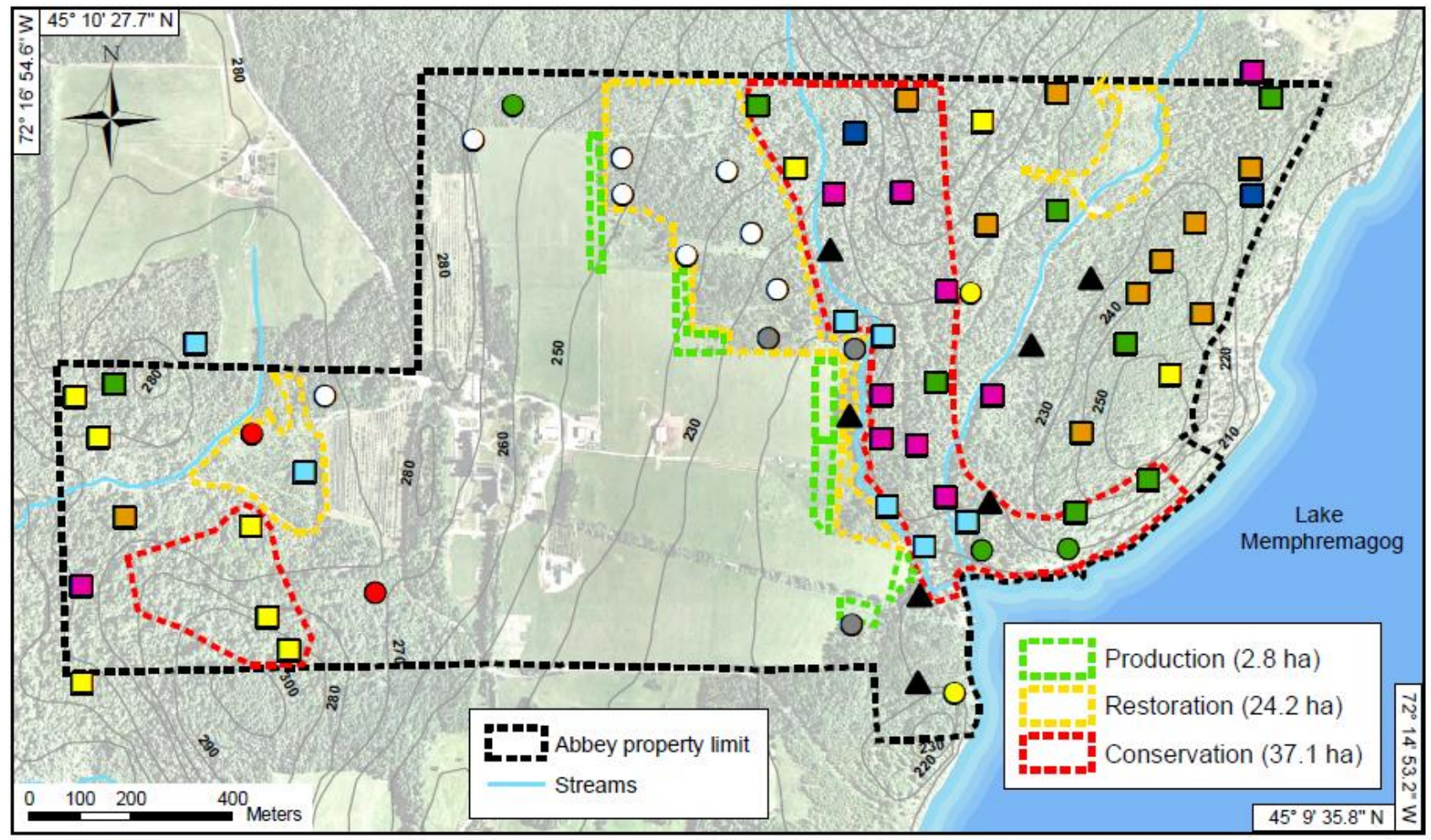

Source : MFFP, QC

\begin{tabular}{|llllllll}
\hline $\mathrm{O}$ & G. birch - b. poplar - elm (Y-1) & $\mathrm{O}$ & Largetooth aspen (Y-4) & $\square$ & Sugar maple - white ash (O-1) & $\square$ & Hemlock - s. maple - y. birch (O-4) \\
$\mathrm{O}$ & Balsam fir (Y-2) & $\bigcirc$ & White pine (Y-5) & $\square$ & Sugar maple - beech (O-2) & $\square$ & Hemlock - y. birch - b. ash (O-5) \\
$\mathrm{O}$ & White ash (Y-3) & $\mathbf{O}$ & Undetermined & $\square$ & Hemlock - sugar maple (O-3) & $\square$ & White cedar (O-6) \\
\hline
\end{tabular}

Figure 4. Projected Base case zoning scenario for the St-Benoît-du-Lac Abbey property. The map includes forest community types (sampled plots), conservation zones, restoration zones and intensive production zones, which are composed of hybrid poplar buffers on the lower slope margins of cultivated fields. All the forest land located outside the conservation zones belongs to the ecosystem management zones, which include the restoration zones. 


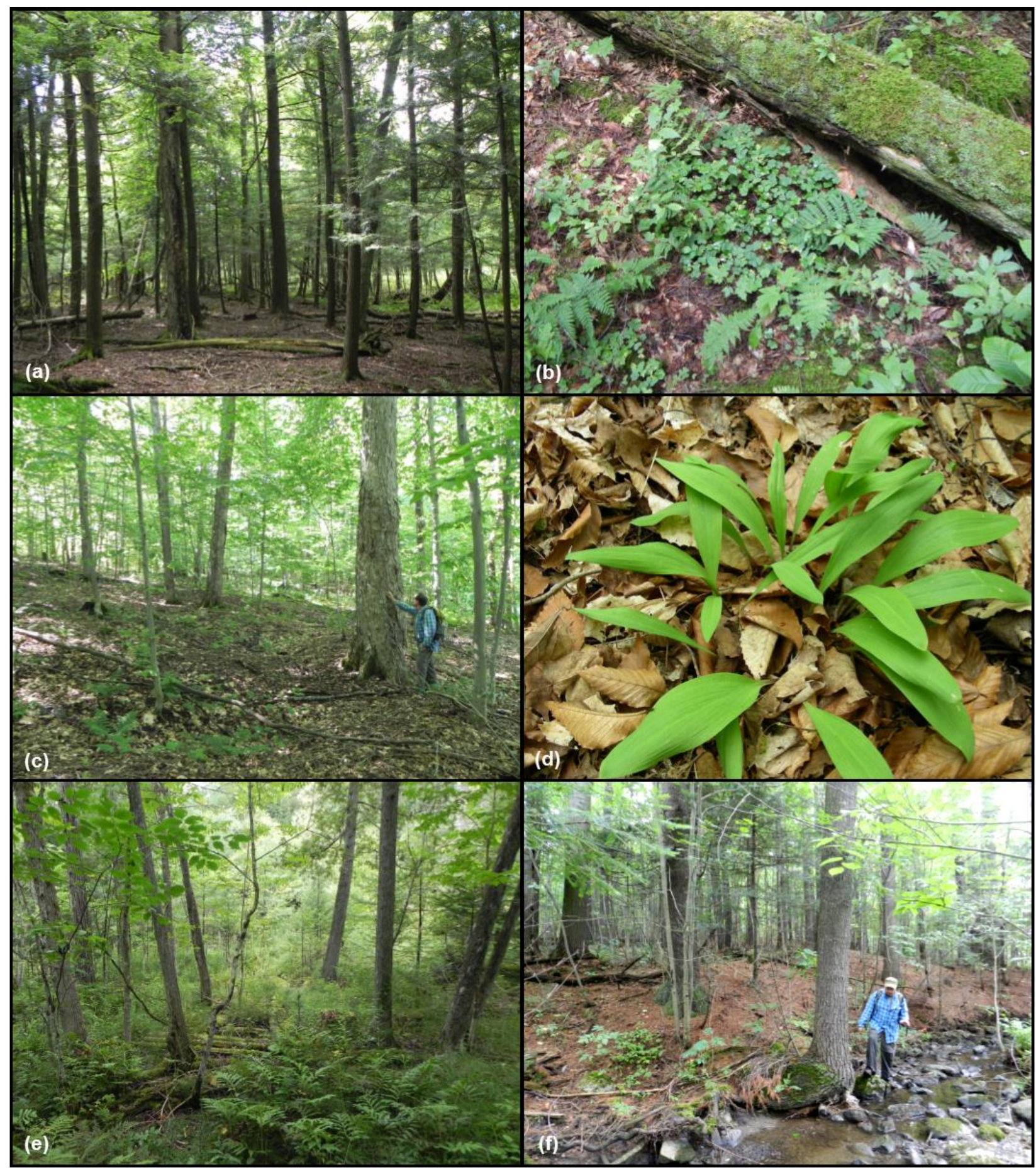

Figure 5. Conservation zone: (a) Old-growth stand (255 years) of the hemlock-sugar maple-yellow birch community type (O-4); (b) Deadwood in old growth hemlock stand (O-4), showing fungi, lichens, bryophytes and tree seedlings, with several more species of bryophytes and vascular plants on the forest floor; (c) Sugar maple-white ash stand (O-1) with a large sugar maple legacy tree; (d) Wild leek (Allium tricoccum), a legally protected species, in rich sugar maple — white ash stands; (e) Degraded white cedar swamp stand (O-6), with small cedar trees and signs of partial harvesting; (f) White pine stand (Y-5), along the edge of the easternmost stream, near the shore of Lake Memphremagog. 
The occurrence of rare plants is another important criterion for determining the position of a conservation zone. We found large populations of wild leek (Allium tricoccum) in sugar maple-white ash community type (O-1) stands (Figure 5). Wild leek is a protected species (with "vulnerable" status) in Québec because of its depletion by past overharvesting [91]. It occurs in species-rich sugar maple forests, which have a high number of tree species and understory herb species [92]. Wild leek serves as an umbrella species for protecting forest understory plant biodiversity. The sugar maple — white ash community type where wild leek was found also contains many large legacy trees (Figure 5), as defined by Mazurek and Zielinski [93], several of which have large cavities and/or hollows (B. Truax, field observations), a key structural attribute for several species of birds, mammals and insects [94]. For these reasons, a second conservation zone is proposed in the stands of the sugar maple - white ash community type, in the south west corner of the property, which covers 7 ha (Figure 4).

Overall, approximately $25 \%$ of the forested land-base at St-Benoît-du-Lac has important or rare compositional and structural attributes for the southern Québec region. Thus, two separate conservation zones are proposed, within the Base case zoning scenario, for a total of 37 ha of protected forest (Figure 4).

\subsection{Delineating Ecosystem Management Zones}

Since 2005, the Québec government has made the commitment to apply ecosystem forest management at a provincial, regional and local scale [48]. In this provincial management context, the remainder of the forested area of the Abbey, not set aside for conservation, is proposed as the ecosystem-based forest management zone.

Ecosystem-based forest management consists in harvesting trees from a forest while at the same time maintaining forest biodiversity, productivity, wildlife habitat attributes, and ecosystem services over the long term [95]. As defined by Grumbine [55] "Ecosystem management integrates scientific knowledge of ecological relationships within a complex sociopolitical and values framework, towards the general goal of protecting native ecosystem integrity over the long term". One of the main goals of forest ecosystem management is to reduce the dissimilarities between managed forests and natural (unmanaged) forests by implementing forestry practices that are inspired by regional patterns of natural disturbances [50,96]. From that perspective, ecosystem management would contribute to maintaining a spatially diverse forest landscape in order to meet the different habitat requirements of a majority of species of animals, plants, fungi and microorganisms [50]. The objective is not to fully restore pre-settlement or pre-industrial forests, but to use historical information to avoid managing forests toward states or dynamics that have never existed in the past [48]. Still, the combined effects of climate change, with its impacts on natural disturbance patterns and on pest outbreaks, along with other human-induced and natural stressors may contribute to produce far different forest ecosystems than those that occurred under pre-settlement conditions, a possibility that needs further analysis, especially in an ecosystem management perspective.

In the study area, past and present factors modifying forest ecosystems are still interacting together, and have created a mosaic of stands at St-Benoît-du-Lac, some of which are poorly stocked and poorly regenerated. Given that St-Benoît-du-Lac was a very strategic location for the water transportation of $\operatorname{logs}$, but also had very fertile soils for settlement agriculture, it could be reasonably hypothesized that most large-sized hardwood trees and pines were cut down within the area of the study site before 1900 
(see Section 2.2). Not all tree species have since been able to recover from these major human disturbances. For example, mature pines, oaks and butternut trees found on the site are scarce and relatively young (>80 years), although they were historically ubiquitous [64,68,97]. Consequently, for forests that have been exploited in the past in a way which is contradictory to the objectives of ecosystem-based forest management, some restoration actions are necessary.

We have elected to concentrate restoration efforts on species from four genera, Pinus, Quercus, Thuja, and Juglans, all very important for local biodiversity and the wood transformation industry. While beech dominated pre-settlement northern hardwoods forests [59], we have chosen not to restore beech within the study area. This is because the population dynamics of this species has been altered by the beech bark disease [98], but also because beech is relatively abundant and well regenerated at the study site. However, old beech trees of large size may become increasingly rare due to beech bark disease. Similarly, ash species, which are also well regenerated at the study site, are threatened by the emerald ash borer (Agrilus planipennis), an Eurasian insect first introduced in United States, that is now attacking ash populations, mainly in urban areas of southern Québec.

\subsubsection{Oak Restoration Zones: Determining Restoration Environments Based on Results from a Long-Term Experiment}

The restoration of oak species in the study area will require the identification of suitable restoration environments because bur oak (Q. macrocarpa) is absent from the study site, and mature red oak (Q. rubra) trees are scarce and their regeneration is minimal. In order to properly map forest environments with high potential for bur oak and red oak restoration, we measured biomass and volume yield, and also the survival of both species in an old experimental design (18 year-old trees) covering a gradient of vegetation types [31]. The Supplementary Materials section contains information on allometric relationships development (Figure S1), along with biomass and volume yield measurements methods and results (Figure S2).

Among all forested environments tested, red oak growth and survival were the best in the early-successional stand dominated by trembling aspen (Populus tremuloides) that had regenerated in an old-field (Figure 6 and Figure S2), which is consistent with the ecology of this mid-successional species [99]. Consequently, targeted sites for red oak restoration are young forest communities composed of deciduous, shade-intolerant species, with a high level of canopy openness, growing on well-drained soils of abandoned fields. Such environment is found in the white ash community type (Y-3), which is characterised by a gentle slope and relatively rich soils (Figures 4 and 6; Table 3). All field-forest ecotones with good drainage, whatever their composition, could also be used for red oak restoration, because forest edges provide favourable light environments for red oak [99]. On the other hand, bur oak is a much slower growing species than red oak, and it has difficulty competing for light in most tree-dominated environments (Figure S2). In natural ecosystems, bur oak typically colonises rich substrates of open bottomland habitats, and it is also able to survive (because of thick cork-like bark) and regenerate following surface fires [70,100]. Bur oak seedlings also showed optimal growth on dry and imperfectly drained soils [33]. Consequently, yield results strongly suggest that environment such as alder thickets may be optimal for bur oak, as they provide good light conditions, high soil fertility and 
high soil moisture (Figure S2). Thus, imperfectly drained old-fields regenerated with shrub species, such as alder or willows, will be used to restore bur oak within the study area.

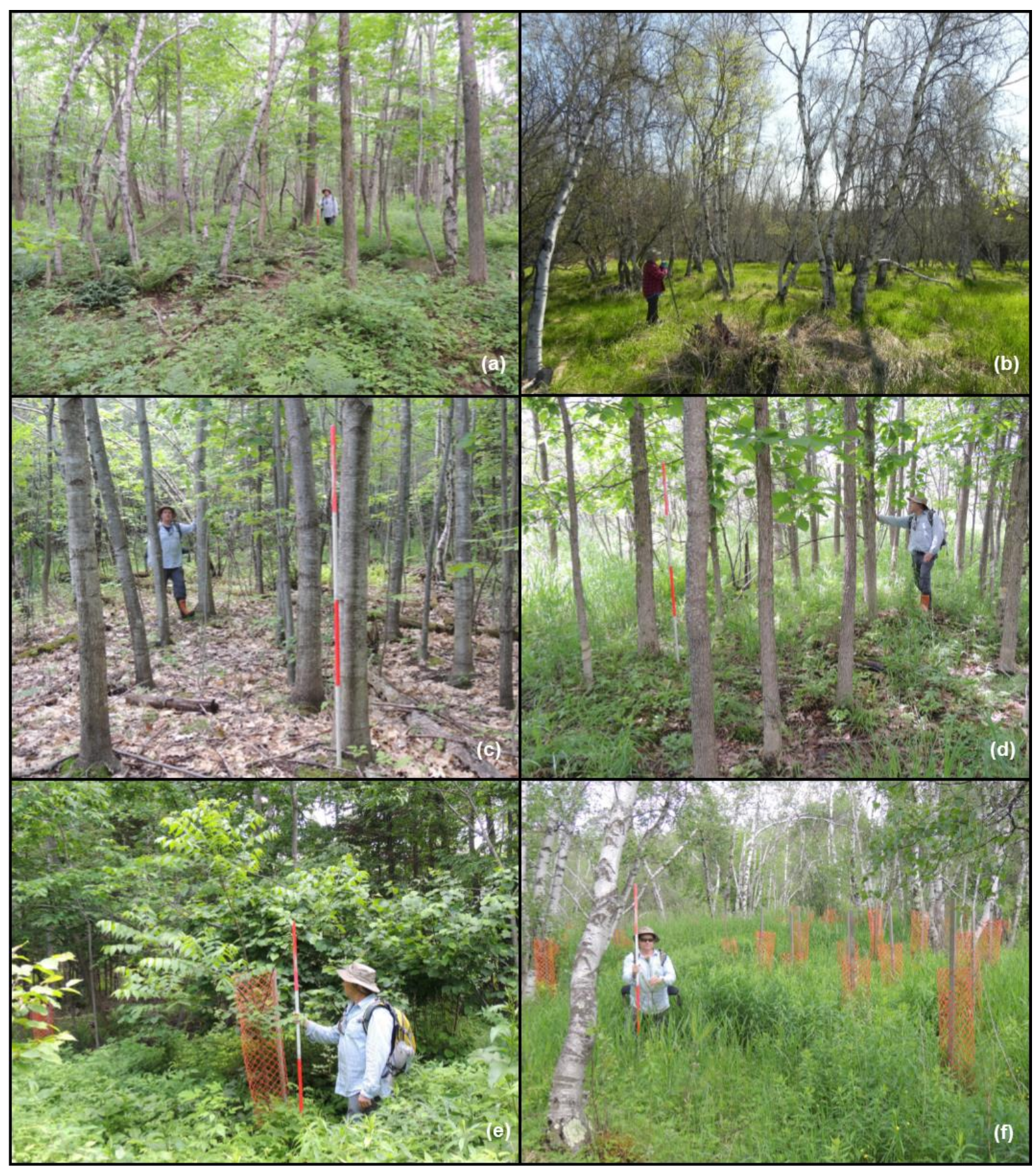

Figure 6. Restoration zones: (a) Post-agricultural abandonment stand (mean age: 47 years) of the white ash community type (Y-3); (b) Post-agricultural abandonment stand (mean age: 40 years) of the very open grey birch—balsam poplar-elm community type (Y-1); (c) Red oak (Quercus rubra) planted in the partially cleared understory of an aspen stand in 1991 (24 years old); (d) Bur oak (Quercus macrocarpa) planted in the partially cleared understory of an alder thicket in 1991 (24 years old); (e) Black walnut (Juglans nigra) planted in the partially cleared understory of a white ash community type (Y-3) stand in 2012 (3 years old); (f) White pine (Pinus strobus) planted in the partially cleared understory of a grey birch (Y-1) stand in 2012 (3 years old). 


\subsubsection{White Pine, Walnut and White Cedar Restoration}

In its natural range, white pine colonizes a wide diversity of sites, including rocky hill tops, sandy soils, peat lands, riparian habitats of streams and lakes, and mesic sites, with optimal growth observed on humid sandy loam soil [100]. Moderately shade-tolerant, white pine often regenerates in forest environments, where it can be under-planted; a strategy that greatly reduces its susceptibility to the pine weevil (Pissodes strobi) [101]. However, growing white pine under too much shade greatly reduces growth and survival, but a canopy openness of 50\%-75\% achieves good growth and acceptable levels of weevil damage [101]. Consequently, on dryer sites, white pine can be restored in similar forest environments to those favourable for red oak, and both of these species frequently co-occur in forest ecosystems [70,99]. For this reason, the white ash community type (Y-3) could also be used for under-planting with white pine (Figure 4). However, because white pine tolerates higher soil moisture levels than red oak [100], imperfectly drained sites dominated by pioneer species are also targeted. Such conditions are found in the very young grey birch-balsam poplar-elm community type that has regenerated in old fields (Y-1) (Figures 4 and 6).

For the case of butternut, the only species from the Juglans genus naturally occurring in the region, we cannot restrict our restoration strategy solely to the reintroduction of native butternut, given that the species may be close to extinction. As exotic pathogens decimate our native trees, the use of exotic species that have similar ecosystem functions and habitat requirements as their native counterpart should be seen as a valuable restoration strategy in a globalised world [80]. We can learn from the catastrophic decline of the American chestnut (Castanea dentata) caused by the Asian fungal pathogen Cryphonectria parasitica [102], and immediately plan the development of disease resistant backcross hybrids between native and exotic genotypes [103]. Such hybrids now provide the opportunity to restore American chestnut to the eastern forests of the United States [104,105]. However, currently, the only restoration strategy that can be employed on the St-Benoit Abbey site will be the use of black walnut (Juglans nigra), as a replacement species for butternut, since black walnut is native to the nearby southern Ontario region, and that it has already been naturalised in southern Québec [100]. Considering the high light and high soil fertility requirements of black walnut, mesic sites dominated by young forests regenerated on old-fields will be used for walnut restoration, such as stands of the white ash community type (Y-3) (Figures 4 and 6).

Unmanaged stands of cedar are characterized by a low rate of canopy disturbance, and by low recruitment of new trees, which makes them highly vulnerable to browsing where deer populations are overabundant [75]. The combination of the very slow growth rate of cedar seedlings and a high deer density have led to the complete elimination of advance regeneration at some sites in the Laurentian and Appalachian forests [106]. At St-Benoit-du-Lac, the increasing abundance of deer threatens the long-term preservation of white cedar along streams and in poorly drained areas, as most cedar regeneration is severely browsed. Where regeneration is already abundant, but highly browsed, deer exclosures, using fencing, are proposed to protect natural regeneration growth [75,107]. A first proposed white cedar restoration zone is located on the western side of the property, just north of the smallest conservation zones, while another proposed cedar restoration zone is a highly degraded cedar swamp located along a small stream on the northeastern part of the Abbey property (Figure 4). 
In short, for the study site, we propose to use three restoration strategies from the four proposed by Stanturf et al. [108]: (1) rehabilitation, which will be used to restore desired species composition and structure in degraded forest stands; (2) reconstruction, which will be used to restore native tree communities on land previously used for agriculture; and (3) the replacement of threatened species (butternut) with a naturalised species (black walnut) will be used as an adaptation to exotic pests. The optimal environmental requirements for the different species to be restored and examples of restoration environments for plantation are summarised in Table 4. All planted trees for restoration purposes will be protected from deer. Additionally, optimal light conditions will be maintained by selective tree felling at different points in time, prior to and after enrichment planting [31]. Consequently, within the ecosystem-based management zones, forest areas under restoration will also provide a timber or biomass supply.

Table 4. Environmental requirements for optimal tree species growth and examples of environments targeted for restoration planting in the ecosystem-based management zones.

The soils of the study site are all loams (loam, clay loam, silty loam).

\begin{tabular}{|c|c|c|}
\hline Species & Species Environmental Requirements & $\begin{array}{c}\text { Potential Restoration Environments within } \\
\text { Study Site } \\
\end{array}$ \\
\hline Red oak & $\begin{array}{l}\text { Low to moderate soil fertility } \\
\text { Rapidly to moderately-well drained soils } \\
\text { Intermediate to high canopy openness }\end{array}$ & $\begin{array}{c}\text { Aspen or ash stands regenerated on old-fields } \\
\text { Forest/old-field edges }\end{array}$ \\
\hline Bur oak & $\begin{array}{l}\text { High soil fertility } \\
\text { Well to imperfectly drained soils } \\
\text { Very high canopy openness }\end{array}$ & $\begin{array}{c}\text { Alder or willow thickets regenerated on } \\
\text { imperfectly drained old-fields } \\
\text { Forest/old-field edges }\end{array}$ \\
\hline White pine & $\begin{array}{l}\text { Low to moderate soil fertility } \\
\text { Rapidly to imperfectly drained soils } \\
\text { Intermediate to high canopy openness }\end{array}$ & $\begin{array}{l}\text { Young grey birch, balsam poplar and aspen } \\
\text { stands regenerated on old-fields }\end{array}$ \\
\hline Black walnut & $\begin{array}{l}\text { Very high soil fertility } \\
\text { Well to moderately-well drained soils } \\
\text { Very high canopy openness }\end{array}$ & $\begin{array}{c}\text { Aspen or ash stands regenerated on old-fields } \\
\text { Forest/old-field edges }\end{array}$ \\
\hline
\end{tabular}

\subsubsection{Silviculture in the Ecosystem Management Zones}

For the remaining forest areas that are not proposed to be set aside for the conservation zones, apart from the restoration zones, we propose that they be managed to produce sawlog, pulp and biomass under the broad principles of ecosystem management. In the study area, small canopy gaps caused by a single tree deaths were the most common form of natural disturbance in the past $[62,64,65]$, which created a finely patterned, diverse mosaic dominated by late-successional species and attributes, with relatively large stands with substantial within-stand diversity in age, and relatively few, uniform single-cohort stands [63]. Different silvicultural treatments have been recommended to achieve ecosystem management goals for northern hardwoods forests, and these will be used as benchmarks for silviculture in the ecosystem management zones.

In mid- and late-successional stands, a gap-based silviculture will be recommended for tree harvesting operations [109]. Most gaps created by single tree or tree clump harvests could range from 24 to $126 \mathrm{~m}^{2}$ gaps, but larger gaps of up to 1000 to $2000 \mathrm{~m}^{2}$ could be created occasionally to favour less tolerant 
species [63]. Various harvesting patterns could be used to create new tree cohorts at rates ranging from 0.7 to $1.3 \%$ per year, to produce average canopy residence times ranging from 75 to 150 years [63]. In more degraded and uniform stands, larger patches or gaps could be created in the near future to provide a large amount of lower quality timber [63], or fuelwood for local needs. Such an operation would also contribute to the natural establishment of more diverse and complex mid- and late-successional communities in degraded stands [63]. All opportunities to conserve legacy trees and advance regeneration of tolerant species will be taken, as they will contribute to restoring late-successional stands dominance [63]. Moreover, being diverse and structurally complex, these late-successional stands would likely be more resilient to global change.

\subsection{Delineating Intensive Production Zones}

Implementing a successful intensive production system is probably the most limiting element of a forest zoning project. The higher the yields in the intensive management zones, the larger the area that can be allocated to forest conservation, because the loss of production in that zone is compensated. It is therefore critical to have realistic yield projections for the study area. Without such information, projected yields in intensive production zones could be greatly overestimated, which would jeopardize the maintenance of timber flow at the land-base level over the long term.

In the province of Québec, the use of hybrid poplar plantations has been proposed to create highly productive intensive production zones, as a basis for zoning projects [110]. However, much of plantation efforts have been done on clear-cut forest sites, where plantation costs are high and yields are disappointing in most cases, even when soil fertilisation and liming are used [111], as observed in other countries [112-114]. Consequently, we do not propose to include the forested areas for intensifying wood production with plantations. Instead, we propose to use agricultural field margins and recently abandoned fields (still dominated by herbaceous vegetation), located downslope of cultivated fields, for the production of woody biomass in multifunctional agroforestry systems.

One of the main goals of the intensive production zone at St-Benoît-du-Lac is to use poplar biomass to partly meet the bioenergy requirements of the Abbey buildings, which consume approximately 450 dry tons of woody biomass annually (Frère Lamontagne, personal communication). Such a strategy would reduce transportation costs and environmental impacts, given that fields planted with poplars will be all located within a radius of less than $600 \mathrm{~m}$ from the monastery. As a Base case scenario, the area allocated to poplar biomass production in agroforestry systems will be adjusted to fully compensate the loss of timber or fuelwood harvest resulting from the integral protection of all the land base having a high conservation value ( 37 ha, or $25 \%$ of the forested land base). Already, 1.2 hectares of field margins and abandoned fields have been planted with hybrid poplars in spring 2011 (Figure 7). The total area of planted poplars will increase in the upcoming years. These agroforestry systems consist of $15 \mathrm{~m}$ wide strips of five tree rows, with a spacing of $2 \mathrm{~m}$ on the row and $3 \mathrm{~m}$ between rows (Figure 7), for a planting density of 1666 stems/ha, which is within recommended density ranges for the production of round wood for bioenergy [115,116]. Ploughing followed by disking was done in the fall (2010) to prepare the site prior to planting (May 2011) and competing vegetation was controlled using local herbicide applications of glyphosate $\left(1 \mathrm{~m}^{2} /\right.$ tree $)$ in June of the first two growing seasons. 


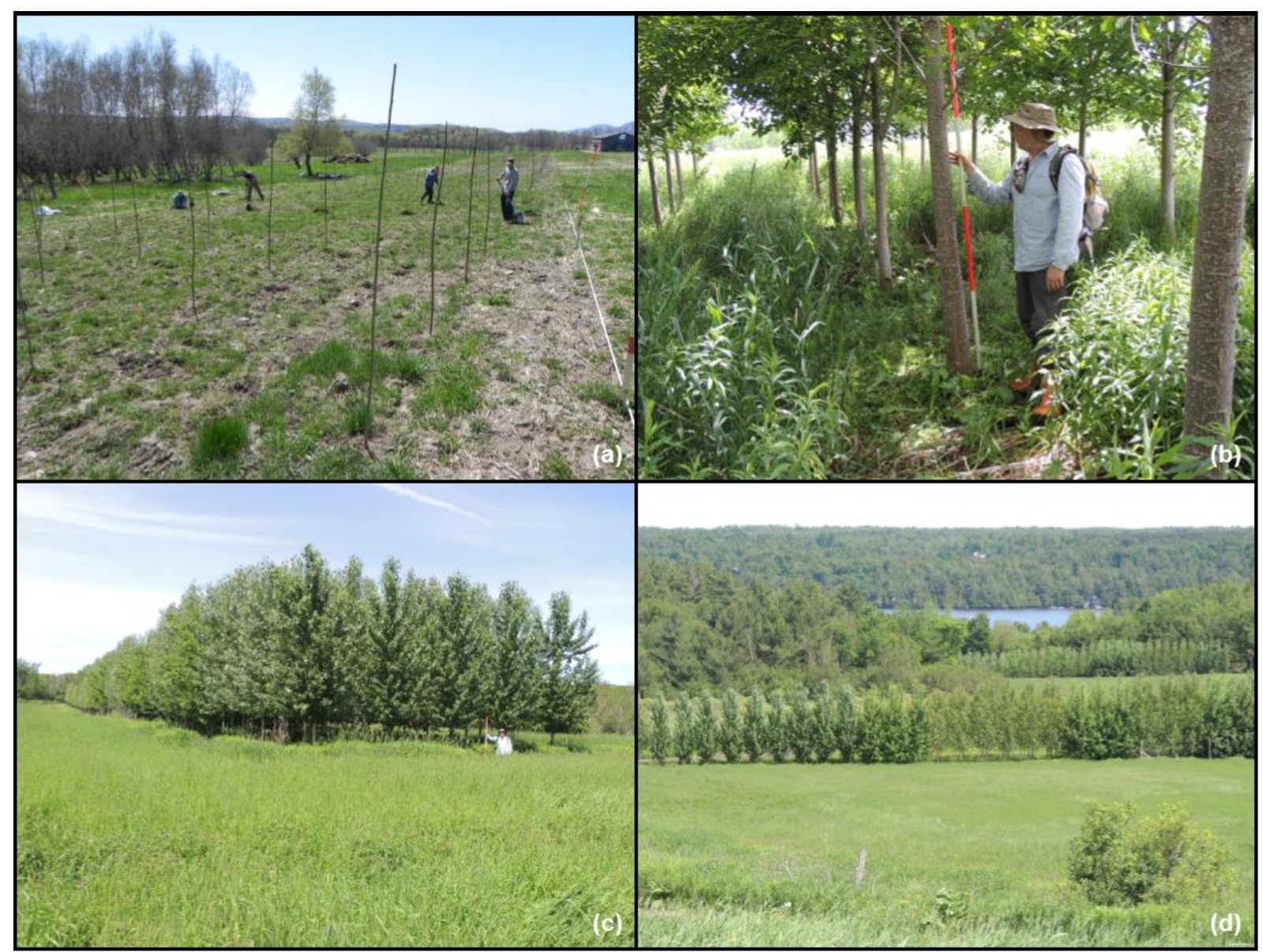

Figure 7. Intensive production zones composed of five rows wide hybrid poplar field-margin buffers (a) during their establishment on the lower slope edges of Abbey fields in May 2011; and (b,c) at the beginning of the fifth growing season in June 2015; (d) landscape perspective of poplar field-margin buffers located upslope from Lake Memphremagog (June 2015).

\subsubsection{Why Use Hybrid Poplars in Buffer Strips along Field Margins?}

There are numerous impacts related to forest production intensification in natural stands, as well as in forest stands converted to native or exotic tree plantations, as rotation length shortens, as forest structure is homogenised and as fertilizer amendments are made. Such impacts may include loss of soil fertility, deterioration of water quality and stream habitat, loss of terrestrial biodiversity and reduction in soil C stocks [117-120]. Harvesting residual biomass (branches, tree crowns) and non-merchantable trees could also be used to increase the quantity of biomass extracted from forests, a strategy that has been allowed by the provincial government [121]. However, impacts on soil fertility, soil C stocks and biodiversity can also occur following residual biomass exploitation [122,123].

To avoid such potential impacts, intensive production zones need to be integrated into the agricultural matrix, in areas where the cumulative ecosystem services will be the greatest. For example, poplars buffers planted down slope of field areas, such as in degraded riparian zones, have been shown to produce very high yields in the region (up to $50 \mathrm{~m}^{3} / \mathrm{ha} /$ year or $21 \mathrm{t} / \mathrm{ha} /$ year), with no direct fertilisation, while providing plant and wildlife habitat, $\mathrm{C}$ storage (above and belowground), and nutrient ( $\mathrm{N}$ and $\mathrm{P}$ ) 
retention and storage [41-44,124-126]. Additionally, using field margins for intensive wood production would not require the creation of additional roads, as they are easily accessed with heavy equipment during harvest or tending operations. Conversely, using forestland to intensify wood production would potentially require the creation of some roads, which would increase habitat fragmentation on a small forest land base.

Soil analyses also suggest that agricultural fields are best suited for sustainable biomass production with fast growing trees in short rotations, rather than forest soils. Mean values from 50 initial composite soil samples taken from agricultural fields (where poplars were planted in 2011) show that field soils have a higher $\mathrm{pH}$ (6.3), are more fertile ( $\mathrm{P}$ and $\mathrm{K}$ ) and more rapidly mineralised (low $\mathrm{C}: \mathrm{N}$ ratio) than forest soils (Table 3). Available P, which is strongly correlated to hybrid poplar growth in the study area $[42,83]$, is 2 to 7 times higher in field soils than in forest soils.

Finally, the establishment of very intensive hybrid poplar production zones also allows for flexibility (in hybrid clone selection) in order to rapidly adapt to changing environmental conditions. Nearly 15 clones of various parentages are recommended for the study area, and new clones are continuously being tested [127].

\subsubsection{Yield and Rotation Length Projections}

The anticipated optimal rotation length for the selected planting density (1666 stems/ha) is calculated using the following regression equation [128]:

$$
R L=16.97-2.844(\log \mathrm{D}) ; R^{2}=0.83
$$

where $R L$ is the rotation length in years, and $D$ the planting density in stems per hectare. Thus, the optimal rotational length for a 1666 stems/ha hybrid poplar plantation would be 8 years.

The anticipated yields of the hybrid poplar agroforestry system at St-Benoît-du-Lac are calculated using two regression equations developed in hybrid poplar plantations and agroforestry systems near the study site. First, we use an equation developed in plantations established on abandoned fields, which uses site elevation, available soil $\mathrm{P}$ and soil $\mathrm{Ca}(0-20 \mathrm{~cm})$, as predictor variables of volume yield after 8 years [83]:

$$
V=-7.24(\ln E)+4.04(\ln P)+1.70(\ln C a)+23 ; R^{2}=0.78
$$

where $V$ is the volume yield ( $\mathrm{m}^{3} /$ ha/year), in terms of mean annual increment, $E$ is site elevation $(\mathrm{m})$, $P$ is available soil $\mathrm{P}(\mathrm{kg} / \mathrm{ha})$, and $C a$ is soil $\mathrm{Ca}(\mathrm{kg} / \mathrm{ha})$. Using a mean site elevation of $230 \mathrm{~m}$ and mean available soil $\mathrm{P}$ and $\mathrm{Ca}$ data of the 50 soil samples collected in the agricultural and old fields dedicated to intensive production (see data in Table 3), the estimated yield of the poplar agroforestry system (with this equation) would be $16.6 \mathrm{~m}^{3} / \mathrm{ha} /$ year. This is probably a very conservative estimate given that the tree density used by Truax et al. [83] to develop this equation was half that of the present study (833 stems/ha vs. 1666 stems/ha) and that poplars from rectangular abandoned field plantations are not subjected to the same nutrient inputs and light levels, compared to the linear buffer strips of this study, which are located down slope from agricultural fields.

We can also use the regression equation of Fortier et al. [42], developed in 9 year-old narrow agricultural riparian buffer strips ( 3 poplar rows on each stream bank, planting density of 2222 stems/ha). This equation uses only soil nutrient content $(0-20 \mathrm{~cm})$, as predictor variables of volume yield: 


$$
V=0.098(P)+0.042(K)+0.0049(C a)-0.023(M g)+12.4 ; R^{2}=0.79
$$

where $V$ is the volume yield $\left(\mathrm{m}^{3} /\right.$ ha/year), in terms of mean annual increment, $P$ is available soil $\mathrm{P}$ ( $\mathrm{kg} / \mathrm{ha}), K$ is soil $\mathrm{K}$ (kg/ha), $C a$ is soil $\mathrm{Ca}(\mathrm{kg} / \mathrm{ha})$, and $M g$ is soil $\mathrm{Mg}(\mathrm{kg} / \mathrm{ha})$. Using soil nutrient content data in Table 3, we obtain a volume yield of $44 \mathrm{~m}^{3} /$ ha/year. This is potentially an overestimation of yields for the study site because the riparian buffers of the Fortier et al. [42] study are narrower and located in the agricultural riparian zones, benefiting from very high resource availability (water, light and nutrients).

We can consider that the field margin buffers from the present study will be intermediate, in terms of production, between large rectangular old-field plantations and narrow agricultural riparian buffer strips. Consequently, as a benchmark to determine the productivity of the intensive production zone, we use the mean yield value estimated using both equations 2 and 3 , which would be $30 \mathrm{~m}^{3} / \mathrm{ha} / \mathrm{year}$, or approximately $13 \mathrm{t} /$ ha/year of woody biomass (stem + branches), using volume to woody biomass ratios obtained on fertile sites in our previous studies [42,45,83,124]. A whole tree dormant season harvest scenario is proposed to maximise nutrient exportation from field areas, as a non-point source agricultural pollution mitigation strategy for aquatic systems [43].

\subsubsection{Area of Intensive Poplar Production Required to Compensate for the Creation of Conservation Zones}

In the privately owned forests of the province of Québec, most of which are located in the southern Québec region, mean forest productivity is approximately $1.8 \mathrm{~m}^{3} / \mathrm{ha} / \mathrm{year}$ [15]. Based on this value, we assume that the harvestable biomass productivity of the forest land set aside for conservation is about $1 \mathrm{t} / \mathrm{ha} /$ year; assuming a mean specific tree green density of $0.56 \mathrm{~g} / \mathrm{cm}^{3}$, and tree bole only harvest, with no residual biomass harvest, in order to maintain forest soil fertility. Based on these assumptions, the projected conservation zones (covering $37 \mathrm{ha}$ ) would have a mean productivity of $37 \mathrm{t}$ of dry biomass annually. Therefore, setting aside this area for conservation would require that $37 \mathrm{t}$ of biomass be produced with hybrid poplars, which would require 2.8 ha of field margins and abandoned fields, at a projected yield of $13 \mathrm{t} / \mathrm{ha} /$ year. Such a scenario would require that less than $6 \%$ of the agricultural land-base (including abandoned fields) be converted to intensive wood production zones to maintain biomass flux at the land base scale, while preserving $25 \%$ of the forest land base (Figure 4 ). The annual production of 37 tons of biomass by poplars could be used to provide $8 \%$ of the annual heating energy needs of the Abbey buildings (450 dry tons per year), considering that all woody species have almost equivalent calorific values [129]. These simple calculations clearly illustrate the potential of fast-growing plantations to reduce harvesting pressures on natural forests [130].

\section{Results and Discussion}

\subsection{Zoning Scenarios for the St-Benoît-du-Lac Abbey Property}

In this case study, we produced different zoning scenarios, starting with the Base case scenario (Figure 4, Table 5), the elements of which are described in the Materials and Methods section. This Base case zoning scenario (Figure 4, Table 5), consists of (1) conservation zones covering $25 \%$ of the forestland ( $37 \mathrm{ha})$; (2) ecosystem management zones covering $75 \%$ of the forestland (113 ha), which 
include restoration zones on $24 \mathrm{ha}$; and (3) an intensive production zone of 2.8 ha composed of hybrid poplar agroforestry systems. This scenario would only require converting a very small proportion of the agricultural land (2.8 ha or $5.6 \%$ of field area) into plantations to allow the conservation of 37 ha of forests with high conservation value. The estimated timber flux from this scenario would be the harvest of $113 \mathrm{t} /$ year from the ecosystem management zones and $37 \mathrm{t} /$ year from the poplar plantations, representing one third of the $450 \mathrm{t}$ of biomass used for heating the Abbey buildings each year, if the harvested wood was used only for bioenergy. However, higher quality wood would be sold for sawlogs, as much as possible. In order to guarantee a constant annual biomass supply, careful planning is needed in the intensive management zone. At a rotation length of 8 years and a productivity of $13 \mathrm{t} / \mathrm{ha} / \mathrm{year}$, the projected intensive production zones (totalising 2.8 ha) should be subdivided into 8 production blocks of 0.36 ha $(13 \mathrm{t} / \mathrm{ha} /$ year $\times 0.36$ ha $\times 8$ years of growth $=37.4 \mathrm{t})$, in order to have one block of 0.36 ha ready to be harvested each year. This zoning scenario would only become effective 8 years following the establishment of the first hybrid poplar production block.

Table 5. Examples of various potential zoning scenarios for the St-Benoît-du-Lac Abbey.

\begin{tabular}{|c|c|c|c|c|c|c|}
\hline Scenarios & Zones & Land Type & Land Area (\%) & Land Area (ha) & $\begin{array}{c}\text { Yield }^{1} \\
\text { (t/ha/year) }\end{array}$ & $\begin{array}{c}\text { Timber Flow } \\
\text { (t/year) }\end{array}$ \\
\hline \multirow[t]{2}{*}{ 0. Current status } & & Forest & 100 & 150 & 1 & 150 \\
\hline & & Fields & 0 & 0 & 0 & 0 \\
\hline \multirow[t]{4}{*}{ 1. Base case } & Conservation & Forest & 25 & 37 & 0 & 0 \\
\hline & Ecosystem & Forest & 75 & 113 & 1 & 113 \\
\hline & Intensive & Fields & 5.6 & 2.8 & 13 & 37 \\
\hline & Total & & & & & 150 \\
\hline \multirow[t]{4}{*}{ 2. Low productivity } & Conservation & Forest & 25 & 37 & 0 & 0 \\
\hline & Ecosystem & Forest & 75 & 113 & 1 & 113 \\
\hline & Intensive & Fields & 9.2 & 4.6 & 8 & 37 \\
\hline & Total & & & & & 150 \\
\hline \multirow[t]{4}{*}{ 3. High productivity } & Conservation & Forest & 25 & 37 & 0 & 0 \\
\hline & Ecosystem & Forest & 75 & 113 & 1 & 113 \\
\hline & Intensive & Fields & 4.1 & 2.1 & 18 & 37 \\
\hline & total & & & & & 150 \\
\hline \multirow[t]{4}{*}{ 4. Energy } & Conservation & Forest & 25 & 37 & 0 & 0 \\
\hline & Ecosystem & Forest & 75 & 113 & 1 & 113 \\
\hline & Intensive & Fields & 51 & 26 & 13 & 337 \\
\hline & Total & & & & & 450 \\
\hline \multirow[t]{4}{*}{ 5. Conservation } & Conservation & Forest & 50 & 75 & 0 & 0 \\
\hline & Ecosystem & Forest & 50 & 75 & 1 & 75 \\
\hline & Intensive & Fields & 11 & 5.8 & 13 & 75 \\
\hline & Total & & & & & 150 \\
\hline
\end{tabular}

\footnotetext{
${ }^{1}$ In all ecosystem management zones the yield or productivity of the natural forest is estimated at $1 \mathrm{t} / \mathrm{ha} / \mathrm{year}$, or $1.8 \mathrm{~m}^{3} / \mathrm{ha} /$ year, which is the yield of privately owned forests in the province of Québec (see Section 2.6.3 for additional details) [15].
}

Based on those projections, the forest zoning concept seems fully applicable to medium-sized private properties of southern Québec, that are characterised by a mixture of cultivated and old fields, and a 
mosaic of young and older forest communities. The application of the Base case scenario (Figure 4, Table 5) appears realistic, from a production perspective, as it would maintain the timber flux at the land base level, compared to the Current status management scenario, where all the forestland is managed for production (Table 5).

It has been argued that if non-timber services are part of a timber management plan on the majority of the forestland, there may be a lesser need for segregating or prioritizing objectives in different areas [131]. However, in a region where small private properties dominate, the diversity of forest services must often be packed into small woodlot areas, which makes integration of intensive forestry (plantations) often incompatible with other services [131]. Integration of timber objectives in high conservation value areas may also be incompatible with biodiversity protection objectives [131]. In such a context, implementing zoning at the private property scale would be a potential solution, as segregated objectives are used in conservation and intensive production zones, while ecological and timber objectives are integrated in the ecosystem management zone. The result is a more multifunctional land base, with different complementary services provided in the different management zones. The use of agroforestry systems to intensify production would further increase multi-functionality because such systems integrate biomass production and agro-environmental objectives.

More specifically, although both projected conservation zones would be relatively small in size (30 ha and $7 \mathrm{ha}$ ) under the Base case scenario, their local conservation value is high, as they contain a diversity of old forest community types, with pre-settlement or late-successional composition and structures; but also streamside, lakeside and swamp habitats; threatened and rare forest herbs; legacy and cavity trees, and a high density of coarse woody debris (Table 3, Figures 4 and 5). Additionally, the largest projected conservation zone forms a forest corridor along a permanent stream, which increases the connectivity between the lake environment and the adjacent forest habitat. Application of ecosystem management on the rest of the forestland would also contribute positively to biodiversity, as ecosystem management aims at promoting natural forest dynamics and processes [55,95]. Projected restoration zones would also contribute to local biodiversity, as several historically important local species will be restored (oaks, white pine, Juglans sp., white cedar) using a variety of approaches (see Section 2.4). At the same time, ecosystem services resulting from the creation of intensive zones with field margin buffers of hybrid poplars would include increased C storage on agricultural land, nutrient trapping, water quality protection, increased farmland habitat quality, and local biomass production for bioenergy $[43,132,133]$. The positioning of those upland buffers between cultivated fields and degraded stands targeted for restoration (Figures 4 and 7) would also contribute to reducing edge effects in those stands, which is important for forest biodiversity [134]. Ashes from burned biomass in the Abbey furnaces could also be recycled and used to maintain soil fertility in agricultural fields and/or intensive management zones, as they are rich in base cations [135]. Allowing forests to age and develop complex structures in both ecosystem management and conservation zones would also increase the $\mathrm{C}, \mathrm{N}$ and $\mathrm{P}$ storage capacity of the forestland [19,21,43,136-138], which is important for global climate regulation, but also nutrient retention in agricultural watersheds.

However, from an economic perspective, there are limitations related to the implementation of such a zoning scenario. Disservices associated with the Base case scenario would include the loss of food production and its revenues on 2.8 ha of arable land, plus the potential agricultural land value loss. Besides, although the productivity of the hybrid poplar agroforestry system could biologically 
compensate for harvest loss in the conservation zone, it is clear that the economic value of poplar biomass would be lower than fuelwood or saw timber generated by late-successional species found in the proposed conservation zones (sugar maple, yellow birch, hemlock, cedar, etc.). Practicing a continuous cover forestry or a gap-based silviculture that would favour stand complexity and uneven-aged structure in the ecosystem management zone could also result in additional costs, compared to clear felling/replanting or extensive management favouring stand homogenisation [139]. On the other hand, restoration of high value species (oaks, walnut, white pine, cedar) would increase timber value on the land base in the long-term.

Another drawback is that without proper financial incentives, zoning of individual properties would probably be difficult to implement. For the moment, numerous existing subsidy programs from different regional and provincial agencies could help to overcome the financial barriers associated with the establishment and tending costs of the silvicultural and agroforestry systems proposed. Regional forest agency programs can cover $80 \%$ of planting, tending and tree protection costs related to abandoned farmland afforestation, but also related to enrichment or under-planting [140]. These programs also cover $80 \%$ of costs related to most types of shelterwood cutting and thinning operations. The Prime-Vert program can cover $70 \%$ of costs related to agroforestry system establishment [141]. Although this provincial program supports wide riparian buffers and windbreak establishment on cultivated land, upland field-margin buffers could also be admissible for financial help (J. Patoine, MAPAQ-Estrie, pers. comm.). The creation of a conservation zone (easement) on a private property is also accompanied by tax reductions, exemptions, and/or credits, depending on the chosen legal status [142].

However, these programs are managed by three different agencies and are not necessarily focused on multi-service provision at the land base level. This highlights the need for developing new subsidy programs that would favour integrative forest/farmland management approaches. Such programs could remove the administrative barriers associated with the preparation and submission of multiple applications for financial support to different agencies, a process that can be very dissuasive. To reduce potential administrative and economic burdens for the land owner, new silvicultural systems (enrichment plantations, hybrid poplar edge buffers, fenced exclosures for regeneration) could be gradually implemented, as it would spread monetary and time investments over several years.

Long-term monitoring of the productivity in the different management zones, but also the monitoring of the integrity of the different forest communities, is a crucial issue of zoning. It is the only way to validate if a project has succeeded or failed at maintaining the timber flux at the land base level, while increasing ecosystem integrity and ecosystem services. In light of data collected over the years, a recalibration of land allocation to different zones could occur if production objectives are not met, or are exceeded, in ecosystem management and intensive management zones. For example, we made the assumption that all restoration zones would have a yield of $1 \mathrm{t} / \mathrm{ha} / \mathrm{year}$ of harvestable biomass. This is a very conservative estimate, especially for white pine, oaks and walnut restoration zones, where trees will be planted on fertile post-agricultural soils, and not on poorer older forest soils (Table 3). Red oak planted at high density can yield up to 4.7-7.8 t/ha/year after 18 years, under extensive management in young secondary forests and in forest/field ecotones, and up to $12.4 \mathrm{t} / \mathrm{ha} /$ year in intensively managed forest/field ecotones (Figure S2 and Figure 6). In that perspective, allocating most forest/field ecotones with good soil drainage to red oak plantations could be an efficient way to meet both ecosystem management and 
intensive management goals, while creating additional conservation opportunities because of yield increases following restoration of degraded stands.

Land managers also need to remain flexible in the way conservation zones are perceived and managed over time [54], as pest invasions or a catastrophic disturbance could destroy most valuable ecological attributes in a conservation zone. For example, if the hemlock woolly adelgid (Adelges tsugae), an exotic insect, migrates north from the southern Appalachian region, where it has caused extensive hemlock mortality [143], it could severely affect the 30 ha conservation zone dominated by hemlock at the study site. If such a pest invasion occurs, a new conservation zone could be created elsewhere, or in situ introductions of pest resistant hemlocks (potentially hybrids) and the use of replacement species with similar structure and functions (ex: white pine) will be required to maintain integrity [143].

In the Low productivity and High productivity scenarios (Table 5), we maintained $25 \%$ of forestland allocation to conservation zones and $75 \%$ of forestland to ecosystem management, but we propose two different hybrid poplar yields in the intensive production zones $(8 \mathrm{t} / \mathrm{ha} /$ year or $18 \mathrm{t} / \mathrm{ha} / \mathrm{year}$, instead of 13 t/ha/year). Both of these scenarios show how yield variation in the intensive zones would directly affect agricultural land allocation to fast-growing woody crops in order to meet the conservation area compensation target. If hybrid poplar yield is lower ( $8 \mathrm{t} / \mathrm{ha} / \mathrm{year})$ than projected, 4.6 ha or $9.2 \%$ of field area would be required to preserve $25 \%$ of the forestland. On the other hand, if very high poplar yields are obtained on the site (18 t/ha/year), as observed in the most productive riparian buffer strip of the region [42,124], only 2.1 ha or $4.1 \%$ of field area would need to be afforested to meet the same conservation compensation target (Table 5). These scenarios highlight the need for prime quality site selection for establishing intensive production zones, as the plantation area and agricultural land conversion required to meet conservation compensation targets are bound to plantation yield [45,111].

The Energy scenario examines the possibility of producing the totality of the biomass fuel requirements of the monastery, which is 450 dry tons per year (Table 5). The implementation of this scenario would require that just over half of the agricultural land (26 out of 50.5 ha) would be afforested with hybrid poplars (mean yield of $13 \mathrm{t} / \mathrm{ha} /$ year) in order to produce $337 \mathrm{t} /$ year of woody biomass, to which $113 \mathrm{t} /$ year would be added from timber harvest in the ecosystem management zones. This scenario highlights that to reach energetic self-sufficiency, for heating several large buildings, a large arable land area is needed, even with productive plantations. Such a level of land use conversion would impinge on ecosystem service provision in the agroecosystem, as food production would sharply decline at the expense of biomass production. Alternatively, a short biomass supply chain could be developed locally, under a cooperative approach with neighbouring forest properties, in order to limit transportation costs and impacts, and guarantee a year over year supply for the monastery buildings. Such a cooperative approach across property boundaries would likely be easier to implement in landscapes that comprise relatively small family farm properties, where neighbours know each other and have a common interest for biomass production despite its low market value [144,145].

The Conservation scenario proposes the creation of protected areas on $50 \%$ of the forestland base or 75 ha (Table 5), which would be feasible with only 5.8 ha or $11 \%$ of field area afforestation with hybrid poplars (mean yield $13 \mathrm{t} / \mathrm{ha} / \mathrm{year}$ ). Thus, little agricultural land conversion to tree plantations would be required to make substantial gains in conservation areas in southern Québec. This situation greatly contrasts with land zoning scenarios developed for less productive forestlands of the boreal shield ecozone. In these northern areas, establishing conservation zones on one hectare requires that one hectare 
of forestland be intensively managed, as intensive management zones are only expected to provide a two-fold yield increase compared to the natural forest [146]. However, for the moment, little scientific evidence suggests that yields can be doubled (only with conifer restocking [146]) on forest sites of the boreal shield, which brings much uncertainty regarding the feasibility of intensively managing large proportions of the land base in northern ecosystems [147,148]. On the other hand, the high yields of afforested plantations and agroforestry systems have been clearly documented for the southern Québec region $[42,45,149,150]$, so land managers and landowners should increasingly use high yielding multifunctional plantations and agroforestry systems, especially in locations where cumulative ecosystem services would be the highest (ex: riparian buffers, field-margin buffers, plantation buffers around already existing woodlots, large shelterbelts or windbreaks, and planted forest corridors between remaining natural forest fragments) [134,151,152].

Finally, although it is not an objective of this study, there is a need to produce an economic evaluation of the different zoning scenarios presented in Table 5, as economic viability is often a condition for the adoption of new silvicultural approaches [139]. Such studies should focus on the value of providing both timber and non-timber services.

\subsection{Management Considerations and Limitations of Applying Forest Zoning at the Single Property Scale: Towards a Multiple-Landowner Approach at the Landscape Level}

From a conservation perspective, it may be argued that creating small forest reserves at the single property scale is of little interest within a forest zoning project. However, small-scale conservation on private land may be more important for regional biodiversity than is generally believed. It is true that large reserves are needed for the protection of some species and that large reserves are easier to manage, but small protected zones can meet fine-filter (genes, populations, species) and coarse-filter (communities, habitats, ecosystems, landscape) conservation objectives, making them important components of ecological networks in fragmented landscapes [18,153]. Reserve size does not always reflect population size nor species diversity, which is an argument in favour of increasing the number of small reserves, especially where key habitat features and rare species or structures occur [18,153], as is the case in the projected conservation zones (Figure 5). As recently reviewed by Humphrey et al. [154], forest patch characteristics (stand structure, species composition and habitat heterogeneity) are of overriding importance for the conservation of all species groups. In that perspective, land zoning should not be restricted to large forest territories, where the possibility to create a reserve network at the landscape and regional scale is far less complicated than in a mosaic of small private landowners with different perceptions of forest and agricultural land management.

For this case study, we had the opportunity to work closely with Abbey managers who were open-minded about developing the zoning project on their land. They were also comfortable with the idea of planting hybrid poplars down slope of their cultivated fields, which implies a certain level of agricultural land conversion. However, agricultural land conversion will not be perceived in the same way by all landowners [35]. In other words, the human factor is of paramount importance in achieving a successful zoning of the land. Motivation (time investment), objectives, knowledge, values and financial situation of private landowners should be fully considered at the planning stage of the project. A one-size-fits-all approach to forest management on private land should be avoided [155], as southern 
Québec private forests are owned by approximately 50,000 landowners, representing a wide diversity of social profiles [16]. Another facilitating element of the present case study is that the Abbey community and its managers will probably remain on the site for several decades to come, which will help achieve long-term management goals and project continuity. Such conditions may also be found on a variety of private properties, as $50 \%$ of all private Québec owners keep possession of their woodlot for more than 20 years [156]. In addition, half of private forest owners of Québec have acquired their forestland from a family member [156], a trend that may assist in the success of long-term projects, as woodlot properties may stay in the same family for decades. In cases where land tenure is shorter, the long-term pursuit of ecosystem management objectives, or the maintenance of biomass production zones in agroforestry systems, may be more complicated, as management objectives may change from owners to owners. At least, under the current provincial legislation, owners can guarantee the perpetuity of their conservation area (with a legal status), independently of future ownership, through a conservation easement agreement [142].

It could also be argued that the study site used to develop the zoning project had all of the desired features to easily implement conservation and intensive management zones (diversity of old-growth forest communities, threatened species, legacy trees, large woody debris, good agroforestry potential, etc.). Indeed, those features are not found on all private properties of southern Québec, which may limit zoning applicability at the single property scale. For example, how can a zoning project be implemented on a property with only young forests or with only agricultural fields and no forest? Within such land constraints, managing the land using forest zoning principles can become a long-term objective.

The most restrictive case would the implementation of forest zoning on a property with no forests and only cultivated fields. In this situation, a complete reconstruction of forest ecosystems would be required to create, in the end, different management zones, including a conservation zone. On such a property, features such as a farm stream, a pond or the woodlot of the neighbor could become the center around which afforestation is undertaken. Fast-growing poplars could be planted for intensive wood production, but also for restoration purposes as poplars form a closed canopy within 10 years, which catalyses the creation of forest attributes important for forest biodiversity [132]. Thereafter, such poplar stands could be under-planted with locally important mid- and late-successional species [31,34], and even with forest herbs that are normally found in late-successional sugar maple stands [157]. Spontaneous ingrowth of many tree species, which characterizes many older poplar plantations (>50 years) [158], could also be managed to favour late-successional species. Also, once planted poplars become mature, some trees could be cut and left on the ground, as large woody debris, while some other trees could be girdled to create large snags, which would diversify stand structure and habitats. When sufficient key structural and compositional attributes are finally restored, the afforested stands could be set aside for conservation or managed under ecosystem management principles. Intensive woody crop production zones could then be created between cultivated fields and planned conservation or ecosystem management zones, in order to buffer the impact of agriculture on restored land.

In a context where $52 \%$ of private forest properties are less than 40 ha in size in the province of Québec [16], there is a need to overcome individual property size and limitations by developing multiple-landowners zoning projects. Such cooperative cross-boundary projects are unavoidable for efficient conservation [144], as ecological networks development in temperate agricultural areas needs to focus on enhancing the size of existing habitat patches and reducing isolation between patches [154]. 
Multiple-landowners projects would also be useful to meet wood production intensification targets, as high quality agricultural fields are not ubiquitous among individual properties. Projects involving many landowners may be difficult to develop because of the level of cooperation they will require, but such projects will likely be the only way to bring forestland zoning to the landscape level in the rural communities of southern Québec. Thus, cooperation bonus incentives should be created to favour cross-boundary forest zoning projects [144], as they already exists for collective riparian buffer establishment on Québec farm streams [141]. Still, in the Eastern Townships region of southern Québec, $40 \%$ of land owners possess between 40 and 100 hectares of forestland, while $17 \%$ of owners possess more than 100 ha [16]. Many of those larger properties may have potential for the application of forest zoning at the single property scale.

A better cooperation between landowners, agricultural land and forestland managers, and their respective governmental agencies will be required to develop successful zoning projects in the rural landscapes of southern Québec. Both forest and agricultural activities should be integrated in management plans, with novel forestry practices (agroforestry, fast-growing tree plantations, multi-functional tree buffers and corridors, enrichment planting, etc.) having high priority, as they will contribute to reducing the environmental impacts of agriculture, to maintaining a competitive forest economy, while reducing land use conflicts. A large public education program should be undertaken in order to promote forestry practices that could create conservation opportunities. For example, $81 \%$ of private landowners in Québec still harvest firewood from their forests [16], and late-successional species such as yellow birch, sugar maple and beech are the most sought after for heating because of their high wood density. This practice could be partly replaced by the production of biomass in hybrid poplar agroforestry systems and plantations, thereby creating conservation opportunities in late-successional stands.

\section{Conclusions}

This case study documents the methods used to create a forest zoning model for a privately owned single property, characterized by both agricultural and forest land uses, a pattern that is typical of the northern temperate forest regions. We have clearly shown how such a model can be applied, delineating realistic forest conservation zones and ecosystem-based forest management zones, using detailed forest vegetation data. Realistic restoration scenarios for several tree species are also proposed for the forest management zone. Furthermore, a small intensive production zone, along cultivated field margins, will eventually supply part of the wood biomass required to heat the Abbey. We can therefore conclude that we can certainly implement a valid and feasible forest zoning system, as well as multifunctional intensive production zones on mixed agricultural and forested properties.

The next challenge will be to assess whether the application of this type of zoning system is also feasible in a multiple-landowner context at the landscape level. Further research needs to be done to define the limits of the system (minimum forested area, minimum forest quality, minimum soil quality). Nevertheless, the recent focus of many private landowners on the amenity functions of forests and on multiple-use forestry offers a tremendous opportunity to reduce the gap between the managed and natural forests of rural landscapes, while improving the environmental value of agroecosystems. 


\section{Supplementary Materials}

Survival, Volume and Biomass Yield of Red and Bur Oak Plantations after 18 Years at St-Benoît-du-Lac

In order to properly map forest environments with high potential for bur oak and red oak restoration, we measured biomass and volume yield, and also the survival of both species in an old experimental design (18 year-old trees) covering a gradient of vegetation types. This experimental design is located within the St-Benoît-du-Lac Abbey property. For additional details see an earlier study by Truax et al. [31]. In the initial study, four tree species growing in different environments were compared for growth and survival. However, for the purpose of this case study, only the results for the two oak species were used. The two ash species, also in the experimental design, are of less interest because they regenerate quite well within the study site. We evaluated biomass, volume and survival of red oaks and bur oaks growing across a gradient of seven plantation environments:

- Old-field - herbicide: located at the forest edge (6 1/ha of glyphosate active ingredient applied in early June in the first 6 growing seasons) (H-field)

- Old-field - control: located at the forest edge (no herbicide treatment) (Field)

- Alder (Alnus rugosa) thicket regenerated in an old-field (Alder)

- Aspen (Populus tremuloides) stand regenerated in an old-field (Poplar)

- Red pine (Pinus resinosa) plantation (Pine)

- Sugar maple (Acer saccharum) forest located on a hilltop (Maple)

- Degraded sugar maple stand located on a cliff (Cliff)

A randomized block plantation design was used in each environment, with three blocks (replicates) and two species of oak, for a total of 42 experimental plots. Each block contained two experimental plots. Each experimental plot was $6 \mathrm{~m} \times 5 \mathrm{~m}$ in size $\left(30 \mathrm{~m}^{2} / \mathrm{plot}\right)$ and contained 20 trees of a single species, for a planting density of 6666 stems/ha. No site preparation was done, except for removing large woody debris and cutting some stems to facilitate plantation in the forested environments. In the spring of 1991, seedlings were planted manually with shovels in four rows of five trees, $1.5 \mathrm{~m}$ between the rows and $1 \mathrm{~m}$ between trees within a row. Bare-root planting stock $(2+0)$, from regional provenance sources, was provided by the Berthier nursery of the Ministère des Ressources naturelles du Québec. A total of 120 seedlings were planted per environment, for a total of 840 seedlings. A shelterwood cut was done in all the forested environments in May of 1994 to produce similar light conditions (approx. 40\% of overstory tree basal area was removed, but no large gaps or edge effects were created). In the spring of 1996, the remaining overstory tree basal area, including the buffer zone, were removed for aspen, red pine and sugar maple stands, resulting in a rectangular gap of $800 \mathrm{~m}^{2}$. However, because of its much smaller overstory tree volume, lower canopy height and higher stem density, the alder stand was not totally cut in 1996 to avoid the re-growth of field vegetation, but instead a partial cut was done again in 1996, as in 1994.

Oak stem volume and stem biomass yield after 18 years were calculated using species-specific allometric relationships developed with material destructively sampled at the end of the 18th growing season. We used a similar sampling and modelling approach as in previous publications with hybrid 
poplars (see Truax et al. [45]). In late October 2008, we selected one representative oak in each experimental plot, for a total 42 trees ( 21 red oaks and 21 bur oaks). In each plot, this representative tree was selected because it was the closest to the average diameter at breast height (DBH) of all trees in the plot. At harvest, the DBH range for the bur oaks was 2.6 to $11.9 \mathrm{~cm}$, and 3.2 to $16.2 \mathrm{~cm}$ for red oaks. After leaf fall, trees were cut just above the root collar and branches were removed from stems, and stems were weighed fresh using a tripod scale. Sub-samples from the stem sections described below were immediately weighed in the field and taken back to the lab for determining dry weight.

In order to calculate stem volume (outside of the bark) for the 42 sampled trees, the following measurements were taken for different DBH classes.

- For large trees $(\mathrm{DBH}>15 \mathrm{~cm})$, stem volume was calculated for five sections of the stem: (1) tree base diameter to $\mathrm{DBH}$; (2) $\mathrm{DBH}$ to $15 \mathrm{~cm}$ diameter; (3) 15 to $10 \mathrm{~cm}$ diameter; (4) 10 to $5 \mathrm{~cm}$ diameter; and (5) 5 to $2 \mathrm{~cm}$ diameter.

- For medium size trees $(\mathrm{DBH}=10-15 \mathrm{~cm})$, stem volume was calculated for four sections of the stem: (1) tree base diameter to $\mathrm{DBH}$; (2) $\mathrm{DBH}$ to $10 \mathrm{~cm}$ diameter; (3) 10 to $5 \mathrm{~cm}$ diameter; and (4) $5 \mathrm{~cm}$ diameter to $2 \mathrm{~cm}$ diameter.

- For small size trees $(\mathrm{DBH}=5-10 \mathrm{~cm})$, stem volume was calculated for three sections of the stem: (1) tree base diameter to $\mathrm{DBH}$; (2) $\mathrm{DBH}$ to $5 \mathrm{~cm}$ diameter; and (3) $5 \mathrm{~cm}$ diameter to $2 \mathrm{~cm}$ diameter.

- For very small trees (DBH $>5 \mathrm{~cm}$ ) volume was calculated for two sections of the stem: (1) tree base diameter to $\mathrm{DBH}$; and (2) $\mathrm{DBH}$ to $2 \mathrm{~cm}$ diameter.

Volumes of different stem sections were then summed to obtain total stem volume for each of the sampled oaks. Volume calculations of each stem section were made using the following equation [159]:

$$
V=\pi / 12\left(D_{1}^{2}+D_{2}^{2}+D_{1} D_{2}\right) L
$$

where, $V$ is the volume of a stem section, $D_{1}$ is the base diameter of the stem section, $D_{2}$ is the diameter at the top of the stem section, and $L$ is the length of the stem section.

With stem volume and stem biomass data of 21 trees per oak species, regression models for stem volume and biomass compartments $v s$. DBH were developed, with DBH being the predictor variable $(x)$ and stem biomass or stem volume being the response variable $(Y)$. Residuals of the different models were plotted and compared to a normal distribution in order to determine the goodness-of-fit according to the Shapiro-Wilk $W$ test. Regression model selection was based on (1) significance of model parameters; (2) the fit $\left(R^{2}\right)$ of the regression, and (3) the goodness of fit $(W)$ or normality in residuals distribution. Selected models are presented in Figure $S 1$.

In order to evaluate volume and biomass production in 18 year-old oak restoration plantations, we recorded DBH values of each living tree in the experimental design using a caliper (mean of two diameter measurements taken perpendicularly). DBH measurements were taken from late October to early November 2008, at the end of the 18th growing season. For each living tree, volume and biomass of different tree components were calculated by inserting the DBH value in the selected species-specific allometric relationships. Then, total plot volume and biomass was calculated by summing volume and biomass of individual living trees in the plot. Total biomass and volume yield data per plot were then scaled up to one hectare. ANOVA was used to test the significance of Environment, Oak species, 
and Environment $\times$ Oak species interaction effects; the standard error of the mean (SE) was used to evaluate differences between means for three levels of significance ${ }^{*} p<0.05$, ** $p<0.01$ and *** $p<0.001)$. All of the ANOVAs were run with the complete set of data ( 7 environments, 2 oak species, 3 blocks $=42$ experimental plots). Stem volume yield, stem biomass yield and survival results are presented in Figure S2.
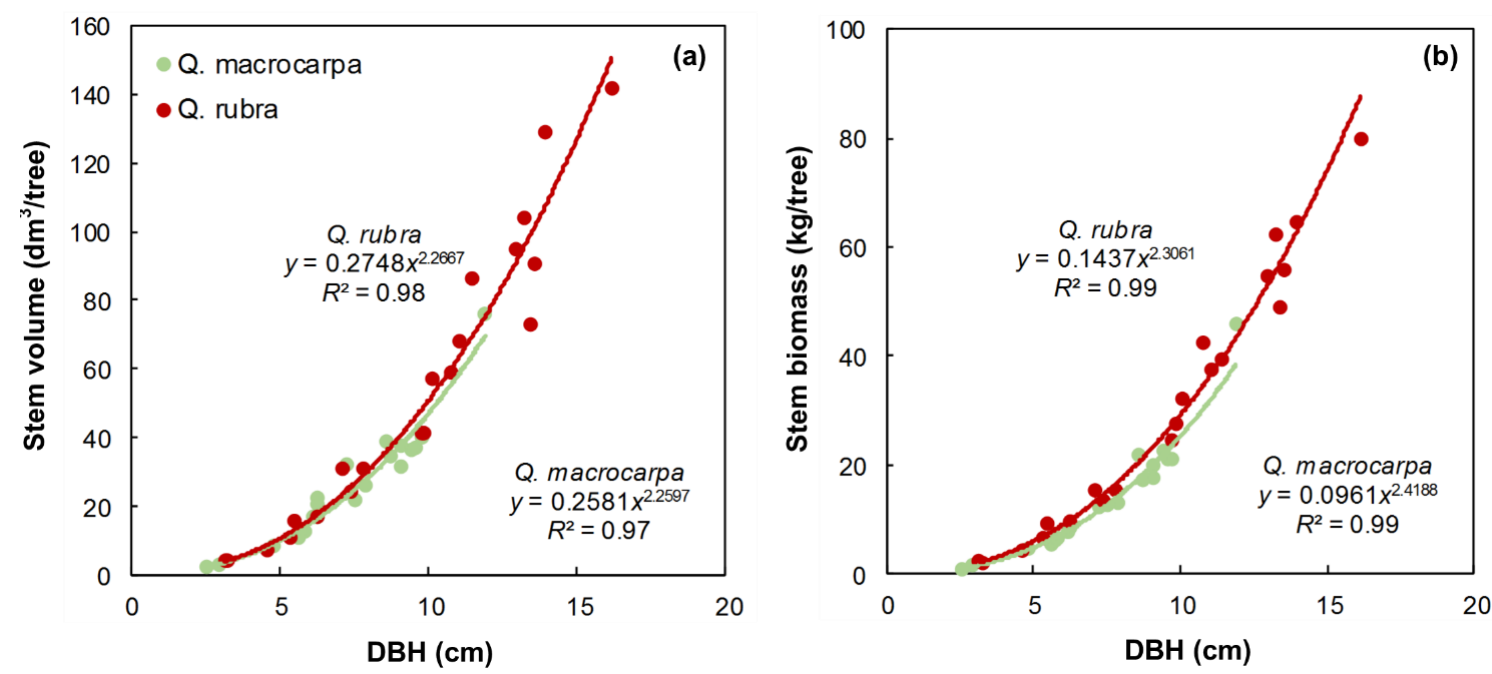

Figure S1. Allometric relationships between DBH, and (a) stem volume or (b) stem biomass in 18 year-old bur oak (Q. macrocarpa) and red oak (Q. rubra) restoration plantations. All relationships and equation parameters are significant at $p<0.001$.
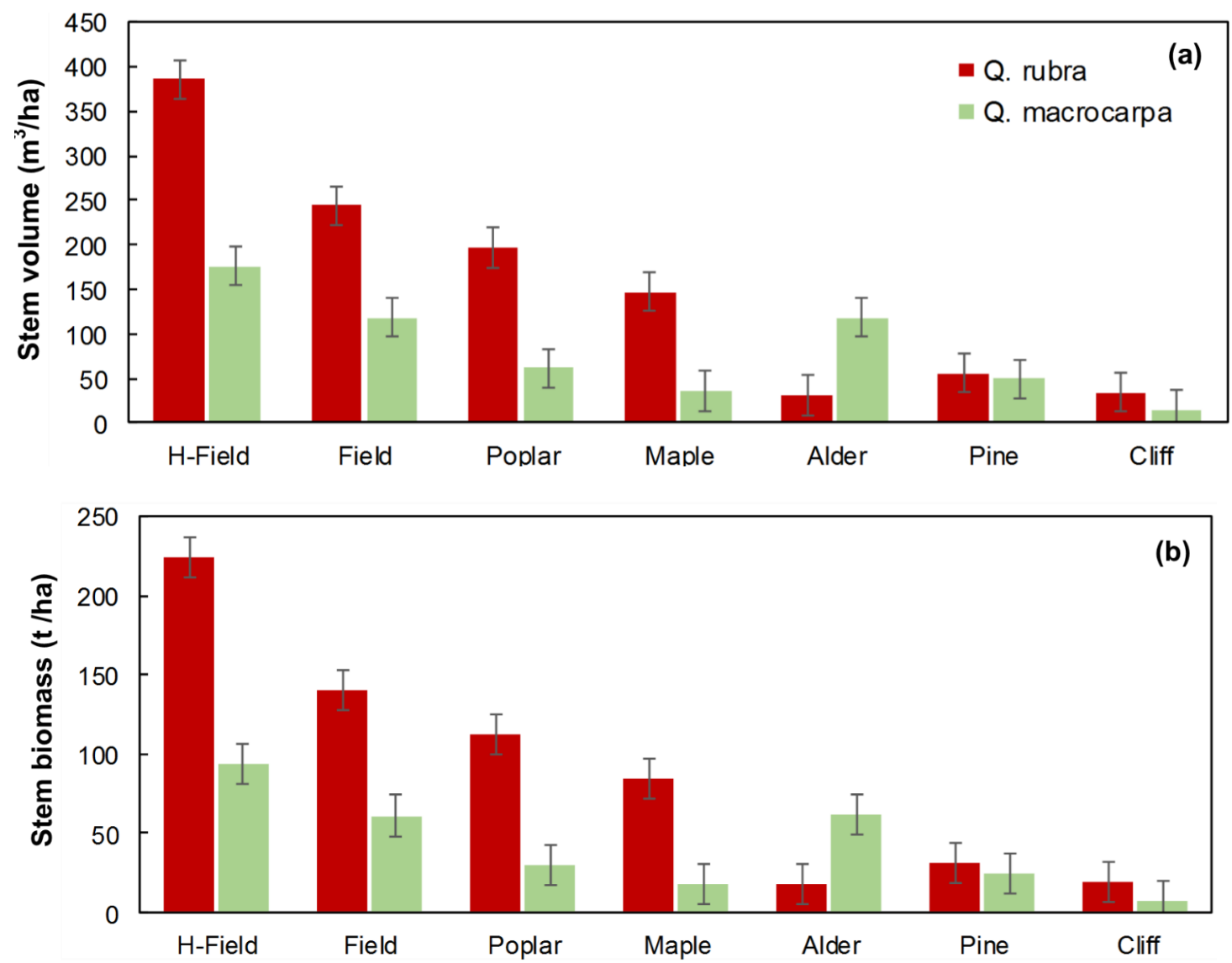

Figure S2. Cont. 


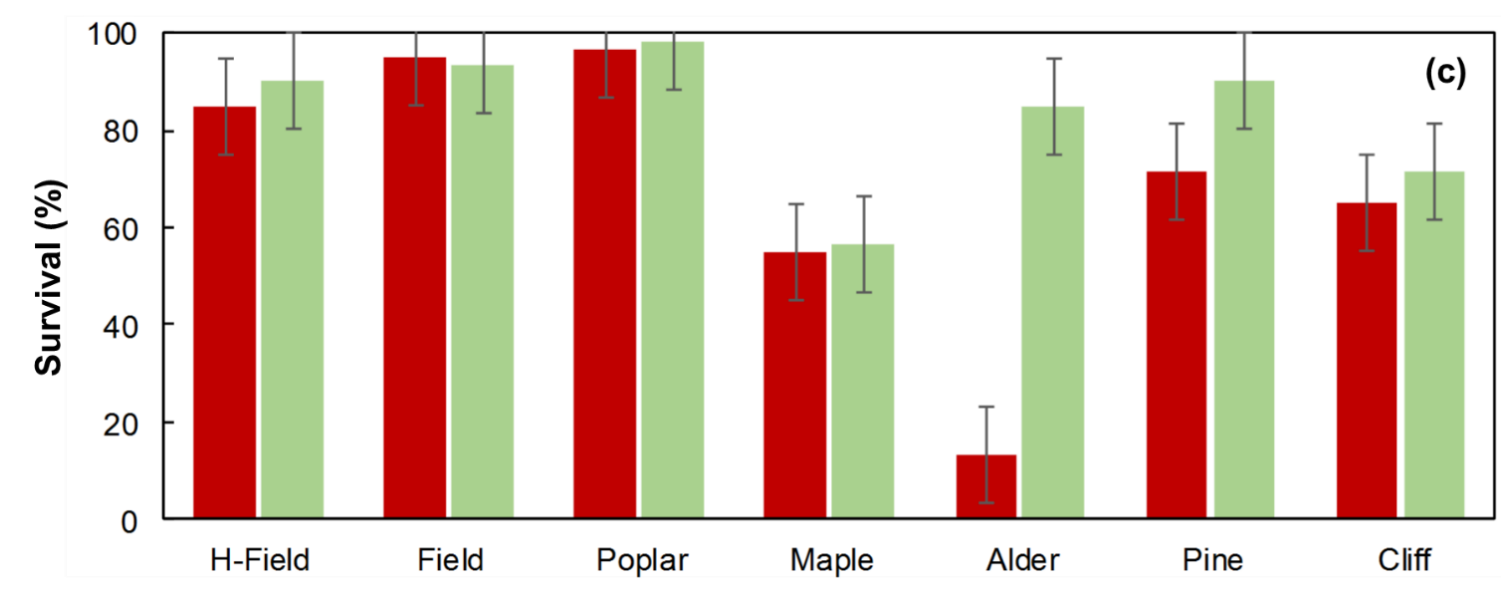

Figure S2. Plantation environment $\times$ Species interaction for (a) total stem volume $(p<0.001)$; (b) total stem biomass $(p<0.001)$; and (c) survival $(p<0.05)$ after 18 years in bur oak ( $Q$. macrocarpa) and $\operatorname{red}$ oak ( $Q$. rubra) restoration plantations. H-field (with herbicide weed control) and Field (no weed control) environments are old-fields located at a forest edge.

\section{Acknowledgments}

We are grateful to the Benedictine Community of St-Benoît-du-Lac for having allowed this project to be carried out on their property and for having given their support to our research projects for over 20 years. We also wish to thank the Ministère des Forêts, de la Faune et des Parcs du Québec (MFFP) ("Chantier sur la forêt feuillue" program and regional funding from "Programme de mise en valeur des ressources du milieu forestier-Volet II"), Natural Resources Canada, and Agriculture and Agri-food Canada (Agricultural Greenhouse Gas Program) for the funding received, as well as many donors: Trees Canada, Novabus, Ski Bromont, Association forestière du sud du Québec and P. Kilburn. We thank K. Boothroyd-Roberts for doing the ordinations (DCAs). Thanks also to C. Cormier (MFFP) for providing the regional map, to E. Lembo (Regional County Municipality of Memphremagog) for providing GIS data for the study site, and to J. Lemelin and A. Richard for creating the land zoning map of the study site. We also acknowledge Dr. R. Bradley and Dr. W. Parsons (Université de Sherbrooke) for doing the soil C/N analyses, as well as S. Gendron and S. Lemay for giving us access to the wood drying facilities of Domtar Corp. (Windsor, QC, Canada). Finally, we wish to thank our field technician (J. Lemelin), our interns and students (M.A. Petrin, A. Richard, A. Laflamme, D. Pageault), and our volunteers (L. Godbout, J.D. Careau, Y. Daigle, S. Wood-Gagnon, S. Gendron). We are grateful to two anonymous reviewers for their constructive and useful comments, which helped to improve this manuscript.

\section{Author Contributions}

The research projects described in this case study were initiated by B. Truax and jointly developed over the years by B. Truax and D. Gagnon. The co-authors listed have contributed equally to producing this article. 


\section{Conflicts of Interest}

The authors declare no conflict of interest.

\section{References}

1. Pan, D.; Domon, G.; de Blois, S.; Bouchard, A. Temporal (1958-1993) and spatial patterns of land use changes in Haut-Saint-Laurent (Quebec, Canada) and their relation to landscape physical attributes. Landsc. Ecol. 1999, 14, 35-52.

2. Bürgi, M.; Turner, M.G. Factors and Processes Shaping Land Cover and Land Cover Changes Along the Wisconsin River. Ecosystem 2002, 5, 184-201.

3. Rey Benayas, J.M.; Martins, A.; Nicolau, J.M.; Schulz, J.J. Abandonment of agricultural land: An overview of drivers and consequences. Perspect. Agric. Vet. Sci. Nat. Res. 2007, 2, 14.

4. Jobin, B.; Latendresse, C.; Baril, A.; Maisonneuve, C.; Boutin, C.; Côté, D. A half-century analysis of landscape dynamics in southern Québec, Canada. Environ. Monit. Assess. 2014, 186, 2215-2229.

5. York, A.M.; Munroe, D.K. Urban encroachment, forest regrowth and land-use institutions: Does zoning matter? Land Use Policy 2010, 27, 471-479.

6. Wiersum, K.F.; Elands, B.M.; Hoogstra, M. Small-scale forest ownership across Europe: Characteristics and future potential. Small-Scale For. 2005, 4, 1-19.

7. Guimond, L.; Simard, M. Gentrification and neo-rural populations in the Québec countryside: Representations of various actors. J. Rural Stud. 2010, 26, 449-464.

8. Butler, B.J.; Leatherberry, E.C. America's family forest owners. J. For. 2004, 102, 4-14.

9. Abrams, J.; Gosnell, H.; Gill, N.; Klepeis, P. Re-creating the Rural, Reconstructing Nature: An International Literature Review of the Environmental Implications of Amenity Migration. Conserv. Soc. 2012, 10, 270-284.

10. Mander, Ü.; Helming, K.; Wiggering, H. Multifunctional land use: Meeting future demands for landscape goods and services. In Multifunctional Land Use; Mander, Ü., Wiggering, H., Helming, K., Eds.; Springer Berlin: Heidelberg, Germany, 2007; pp. 1-13.

11. Paquette, S.; Domon, G. Trends in rural landscape development and sociodemographic recomposition in southern Quebec (Canada). Landsc. Urban Plan. 2001, 55, 215-238.

12. Paquette, S.; Domon, G. Changing ruralities, changing landscapes: Exploring social recomposition using a multi-scale approach. J. Rural Stud. 2003, 19, 425-444.

13. Dupras, J.; Alam, M. Urban Sprawl and Ecosystem Services: A Half Century Perspective in the Montreal Area (Quebec, Canada). J. Environ. Policy Plan. 2014, 1-21.

14. CAAAQ. Agriculture et Agroalimentaire: Assurer et Bâtir L'avenir, Propositions pour une Agriculture Durable et en Santé. Rapport de la Commission sur L'avenir de L'agriculture et de L'agroalimentaire Québécois; Québec, QC, Canada, 2008.

15. Commission d'étude sur la gestion de la forêt publique québécoise. Chapitre 2-Les Forêts Québécoises: Territoire, Ressources et Usages; Gouvernement du Québec: Québec, QC, Canada, 2004; pp. 7-34. 
16. Côté, M.-A.; Gilbert, D.; Nadeau, S. Caractérisation des Profils, des Motivations et des Comportements des Propriétaires Forestiers Québécois par Territoire D’agence régionale de Mise en Valeur des Forêts Privées. Rapport Produit pour le Compte des Agences Régionales de Mise en Valeur des Forêts Privées et du Ministère des Ressources Naturelles du Québec; La Fédération des Producteurs Forestiers du Québec; Le Groupe AGÉCO et Ressources Naturelles Canada: Québec, QC, Canada, 2012.

17. Brassard, F.; Bouchard, A.R.; Boisjoly, D.; Poisson, F.; Bazoge, A.; Bouchard, M.-A.; Lavoie, G.; Tardif, B.; Bergeron, M.; Perron, J.; et al. Portrait du Réseau D’aires Protégées au Québec: Période 2002-2009; Ministère du Développement durable de l'Environnement et des parcs du Québec: Québec, QC, Canada, 2010; p. 41.

18. Götmark, F.; Thorell, M. Size of nature reserves: Densities of large trees and dead wood indicate high value of small conservation forests in southern Sweden. Biodivers. Conserv. 2003, $12,1271-1285$.

19. Alexandrov, G. Carbon stock growth in a forest stand: The power of age. Carbon Balance Manag. 2007, 2, 1-5.

20. Hooker, T.D.; Compton, J.E. Forest ecosystem carbon and nitrogen accumulation during the first century after agricultural abandonnement. Ecol. Appl. 2003, 13, 299-313.

21. Lewis, D.B.; Castellano, M.J.; Kaye, J.P. Forest succession, soil carbon accumulation, and rapid nitrogen storage in poorly remineralized soil organic matter. Ecology 2014, 95, 2687-2693.

22. Rousseau, A.N.; Mailhot, A.; Slivitzky, M.; Villeneuve, J.-P.; Rodriguez, M.J.; Bourque, A. Usages et approvisionnement en eau dans le sud du Québec Niveau des connaissances et axes de recherche à privilégier dans une perspective de changements climatiques. Can. Water Res. J. 2004, 29, 121-134.

23. Hudon, C.; Carignan, R. Cumulative impacts of hydrology and human activities on water quality in the St. Lawrence River (Lake Saint-Pierre, Quebec, Canada). Can. J. Fish. Aquat. Sci. 2008, 65, 1165-1180.

24. De La Chenelière, V.; Brodeur, P.; Mingelbier, M. Restauration des habitats du lac Saint-Pierre: Un prérequis au rétablissement de la perchaude. Nat. Can. 2014, 138, 50-61.

25. Galvez-Cloutier, R.; Sanchez, M. Trophic Status Evaluation for 154 Lakes in Quebec, Canada: Monitoring and Recommendations. Water Qual. Ressour. J. Can. 2007, 42, 252-268.

26. Chu, C.; Minns, C.K.; Lester, N.P.; Mandrak, N.E. An updated assessment of human activities, the environment, and freshwater fish biodiversity in Canada. Can. J. Fish. Aquat. Sci. 2015, 72, $135-148$.

27. Simard, H.; Bouchard, A. The precolonial 19th century forest of the Upper St. Lawrence Region of Quebec: A record of its exploitation and transformation through notary deeds of wood sales. Can. J. For. Res. 1996, 26, 1670-1676.

28. AFCE. Les Grands Pins au Québec: Un Choix D'avenir; Association Forestière des Cantons-de-l'Est: Québec, QC, Canada, 2008; p. 34.

29. Giguère, M. L'industrie de la Transformation du Bois au Québec; Direction du Développement de L'industrie des Produits Forestiers; Ministère des Ressources Naturelles: Québec, QC, Canada, 2012; p. 126. 
30. Truax, B.; Gagnon, D. Effects of straw and black plastic mulching on the initial growth and nutrition of butternut, white ash and bur oak. For. Ecol. Manag. 1993, 57, 17-27.

31. Truax, B.; Lambert, F.; Gagnon, D. Herbicide-free plantations of oaks and ashes along a gradient of open to forested mesic environments. For. Ecol. Manag. 2000, 137, 155-169.

32. Lambert, F.; Truax, B.; Gagnon, D.; Chevrier, N. Growth and N nutrition, monitored by enzyme assays, in a hardwood plantation: Effects of mulching materials and glyphosate application. For. Ecol. Manag. 1994, 70, 231-244.

33. Cogliastro, A.; Gagnon, D.; Bouchard, A. Experimental determination of soil characteristics optimal for the growth of ten hardwoods planted on abandoned farmland. For. Ecol. Manag. 1997, 96, 49-63.

34. Gardiner, E.S.; Stanturf, J.A.; Schweitzer, C.J. An afforestation system for restoring bottomland hardwood forests: Biomass accumulation of nuttall oak seedlings interplanted beneath eastern cottonwood. Restor. Ecol. 2004, 12, 525-532.

35. Neumann, P.D.; Krahn, H.J.; Krogman, N.T.; Thomas, B.R. "My grandfather would roll over in his grave": Family farming and tree plantation on farmland. Rural Sociol. 2007, 72, 111-135.

36. McKenney, D.W.; Yemshanov, D.; Fraleigh, S.; Allen, D.; Preto, F. An economic assessment of the use of short-rotation coppice woody biomass to heat greenhouses in southern Canada. Biomass Bioenergy 2011, 35, 374-384.

37. Lantz, V.A.; Chang, W.-Y.; Pharo, C. Benefit-cost analysis of hybrid willow crop production on agricultural land in eastern Canada: Assessing opportunities for on-farm and off-farm bioenergy use. Biomass Bioenergy 2014, 63, 257-267.

38. Rockwood, D.L.; Naidu, C.V.; Carter, D.R.; Rahmani, M.; Spriggs, T.A.; Lin, C.; Alker, G.R.; Isebrands, J.G.; Segrest, S.A. Short-rotation woody crops and phytoremediation: Opportunities for agroforestry? Agrofor. Syst. 2004, 61-62, 51-63.

39. Ferrarini, A.; Serra, P.; Almagro, M.; Trevisan, M.; Amaducci, S. Linking Bioenergy and ecological services along field margins: The hedge-biomass project In Proceedings of the 22nd European Biomass Conference and Exibition, Hamburg, Germany, 23-26 June 2014; pp. 257-273.

40. Licht, L.A.; Isebrands, J.G. Linking phytoremediated pollutant removal to biomass economic opportunities. Biomass Bioenergy 2005, 28, 203-218.

41. Fortier, J.; Gagnon, D.; Truax, B.; Lambert, F. Understory plant diversity and biomass in hybrid poplar riparian buffer strips in pastures. New For. 2011, 42, 241-265.

42. Fortier, J.; Truax, B.; Gagnon, D.; Lambert, F. Mature hybrid poplar riparian buffers along farm streams produce high yields in response to soil fertility assessed using three methods. Sustainability 2013, 5, 1893-1916.

43. Fortier, J.; Truax, B.; Gagnon, D.; Lambert, F. Biomass carbon, nitrogen and phosphorus stocks in hybrid poplar buffers, herbaceous buffers and natural woodlots in the riparian zone on agricultural land. J. Environ. Manag. 2015, 154, 333-345.

44. Pageault, D. Effet de Bandes Riveraines Plantées de Peupliers Hybrides sur la Présence et L'abondance de Micromammifères et de Picidés en Zone Agricole du sud du Québec. Master's Thesis, Université du Québec à Montréal, Montréal, QC, Canada, 2013. 
45. Truax, B.; Gagnon, D.; Fortier, J.; Lambert, F. Biomass and volume yield in mature hybrid poplar plantations on temperate abandoned farmland. Forests 2014, 5, 3107-3130.

46. Gouvernement du Québec. Loi sur L'Aménagement Durable du Territoire Forestier; Éditeur officiel du Québec, 2015.

47. Jetté, J.-P.; Leblanc, M.; Bouchard, M.; Villeneuve, N. Intégration des Enjeux Écologiques dans les Plans D’aménagement Forestier Intégré, Partie I-Analyse des Enjeux; Gouvernement du Québec; Ministère des Ressources Naturelles; Direction de L'aménagement et de L'environnement Forestiers: Québec, QC, Canada, 2013; p. 150.

48. Grenon, F.; Jetté, J.-P.; Leblanc, M. Manuel de Référence pour L'aménagement Écosystémique des Forêts au Québec-Module 1-Fondements et Démarche de la Mise en Oeuvre. Centre D'enseignement et de Recherche en Foresterie de Sainte-Foy Inc. et Ministère des Ressources Naturelles et de la Faune; Direction de L'environnement et de la Protection des Forêts: Québec, QC, Canada, 2010.

49. Binkley, C. Ecosystem management and plantation forestry: New directions in British Columbia. New For. 1999, 18, 75-88.

50. Hunter, M.L. Wildlife, Forests, and Forestry: Principles for Managing Forests for Biological Diversity; Prentice Hall: Englewood Cliffs, NJ, USA, 1990; p. 370.

51. Sahajananthan, S.; Haley, D.; Nelson, J. Planning for Sustainable Forests in British Columbia through Land Use Zoning. Can. Public Policy 1998, 24, S73-S81.

52. Messier, C.; Tittler, R.; Kneeshaw, D.D.; Gélinas, N.; Paquette, A.; Berninger, K.; Rheault, H.; Meek, P.; Beaulieu, N. TRIAD zoning in Quebec: Experiences and results after 5 years. For. Chron. 2009, 85, 885-896.

53. Montigny, M.K.; MacLean, D.A. Triad forest management: Scenario analysis of forest zoning effects on timber and non-timber values in New Brunswick, Canada. For. Chron. 2006, 82, 496-511.

54. Simoncic, T.; Boncina, A.; Rosset, C.; Binder, F.; Meo, I.D.; Cavlovic, J.; Gal, J.; Matijasic, D.; Schneider, J.; Singer, F.; et al. Importance of priority areas for multi-objective forest planning: A central european perspective. Int. For. Rev. 2013, 15, 509-523.

55. Grumbine, R.E. What is ecosystem management? Conserv. Biol. 1994, 8, 27-38.

56. Association Maritime du Québec. Lac Memphrémagog. Available online: http://www.navigationquebec.com/fiche_lac.php?1_id=46 (accessed on 14 June 2015).

57. Robitaille, A.; Saucier, J.-P. Paysages Régionaux du Québec Méridional; Les Publications du Québec: Ste-Foy, QC, Canada, 1998; p. 213.

58. Westveld, M. Natural forest vegetation zones of New England. J. For. 1956, 54, 332-338.

59. Cogbill, C.V.; Burk, J.; Motzkin, G. The forests of presettlement New England, USA: Spatial and compositional patterns based on town proprietor surveys. J. Biogeogr. 2002, 29, 1279-1304.

60. Cann, D.B.; Lajoie, P. Études des Sols des Comtés de Stanstead, Richmond, Sherbrooke et Compton dans la Province de Québec; Ministère de l'Agriculture: Ottawa, ON, Canada, 1943; p. 58.

61. Comité d'experts sur la prospection pédologique d'Agriculture Canada. Le Système Canadien de Classification des Sols. Publication No. 1646, 2nd ed.; Agriculture Canada: Ottawa, ON, Canada,1987; p. 170. 
62. Lorimer, C.G. The presettlement forest and natural disturbance cycle of northeastern Maine. Ecology 1977, 58, 139-148.

63. Seymour, R.S.; White, A.S.; deMaynadier, P.G. Natural disturbance regimes in northeastern North America—evaluating silvicultural systems using natural scales and frequencies. For. Ecol. Manag. 2002, 155, 357-367.

64. Nichols, G.E. The hemlock-white pine-northern hardwood region of eastern North America. Ecology 1935, 16, 403-422.

65. Runkle, J.R. Patterns of disturbance in some old-growth mesic forests of eastern North America. Ecology 1982, 63, 1533-1546.

66. Brisson, J.; Bouchard, A. In the past two centuries, human activities have caused major changes in the tree species composition of southern Québec, Canada. Écoscience 2003, 10, 236-246.

67. Booth, J.D. Timber utilization on the agricultural frontier in southern Québec. J. Eastern Twonships Stud. 1994, 4, 15-30.

68. Kesteman, J.-P.; Southam, P.; Saint-Pierre, D. Histoire des Cantons-de-l'Est. Les Presses de l’Université Laval: Ste-Foy, QC, Canada, 1998.

69. Marie-Victorin, F.; Rouleau, E.; Brouillet, L.; Hay, S.G.; Goulet, I. Flore Laurentienne-3e Édition; Gaëtan Morin Éditeur Ltée: Montréal, QC, Canada, 2002; p. 1093.

70. Abrams, M.D. Fire and the development of oak forests. BioScience 1992, 42, 346-353.

71. Weyenberg, S.A.; Frelich, L.E.; Reich, P.B. Logging versus fire: How does disturbance type influence the abundance of Pinus strobus regeneration? Silva Fenn. 2004, 38, 179-194.

72. MRNF. Le Plan de Gestion du Cerf de Virginie au Québec 2010-2017; Direction de l'expertise sur la faune et ses habitats, Ministère des ressources naturelles et de la faune: Québec, QC, Canada, 2010.

73. Kittredge, D.B.; Ashton, P.M.S. Impact of deer browsing on regeneration in mixed stands in southern New England. North. J. Appl. For. 1995, 12, 115-120.

74. Rooney, T.P. Deer impacts on forest ecosystems: A North American perspective. Forestry 2001, 74, 201-208.

75. Boulfroy, E.; Forget, E.; Hofmeyer, P.V.; Kenefi, L.S.; Larouche, C.; Lessard, G.; Lussier, J.-M.; Pinto, F.; Ruel, J.-C.; Weiskittel, A. Silvicultural Guide for Northern White-Cedar (Eastern White Cedar); Gen. Tech. Rep. NRS-98; U.S. Department of Agriculture, Forest Service, Northern Research Station: Newtown Square, PA, USA, 2012; p. 74.

76. Villeneuve, N.; Brisson, J. Old-growth forests in the temperate deciduous zone of Quebec: Identification and evaluation for conservation and research purposes. For. Chron. 2003, 79, 559-569.

77. COSEWIC. Butternut Juglans cinerea. Available online: http://www.cosewic.gc.ca/eng/sct1/ searchdetail_e.cfm?id=793\&StartRow=1\&boxStatus=All\&boxTaxonomic=All\&location=All\&c hange $=$ All\&board=All \&commonName $=$ butternut $\&$ scienceName $=\&$ returnFlag $=0 \&$ Page $=1$ (accessed on 22 May 2015).

78. Tanguay, C. Distribution, Abondance et État de Santé du Noyer Cendré (Juglans cinerea) en Relation avec les Gradients Écologiques dans les Cantons-de-l'Est. Master's Thesis, Université du Québec à Montréal, Montréal, QC, Canada, 2011. 
79. Allen, C.D.; Macalady, A.K.; Chenchouni, H.; Bachelet, D.; McDowell, N.; Vennetier, M.; Kitzberger, T.; Rigling, A.; Breshears, D.D.; Hogg, E.H.; et al. A global overview of drought and heat-induced tree mortality reveals emerging climate change risks for forests. For. Ecol. Manag. 2010, 259, 660-684.

80. Dale, V.H.; Joyce, L.A.; McNulty, S.; Neilson, R.P.; Ayres, M.P.; Flannigan, M.D.; Hanson, P.J.; Irland, L.C.; Lugo, A.E.; Peterson, C.J.; et al. Climate change and forest disturbances. BioScience 2001, 51, 723-734.

81. Gauthier, S.; Bernier, P.; Kuuluvainen, T.; Shvidenko, A.Z.; Schepaschenko, D.G. Boreal forest health and global change. Science 2015, 349, 819-822.

82. Hanson, P.J.; Weltzin, J.F. Drought disturbance from climate change: Response of United States forests. Sci. Tot. Environ. 2000, 262, 205-220.

83. Truax, B.; Gagnon, D.; Fortier, J.; Lambert, F. Yield in 8 year-old hybrid poplar plantations on abandoned farmland along climatic and soil fertility gradients. For. Ecol. Manag. 2012, 267, 228-239.

84. Fortier, J.; Truax, B.; Gagnon, D.; Lambert, F. Plastic allometry in coarse root biomass of mature hybrid poplar plantations. BioEnergy Res. 2015, 1-14.

85. Oksanen, J.; Blanchet, F.G.; Kindt, R.; Legendre, P.; O’Hara, R.B.; Simpson, G.L.; Solymos, P.; Stevens, M.H.H.; Wagner, H. Vegan: Community Ecology Package. R Package Version 1.17-11. Available online: http://CRAN.R-project.org/package=vegan. (accessed on 4 December 2011).

86. Savignac, C.; Desrochers, A.; Huot, J. Habitat use by Pileated Woodpeckers at two spatial scales in eastern Canada. Can. J. Zool. 2000, 78, 219-225.

87. Trudeau, C.; Imbeau, L.; Drapeau, P.; Mazerolle, M.J. Site occupancy and cavity use by the northern flying squirrel in the boreal forest. J. Wildlife Manag. 2011, 75, 1646-1656.

88. Brisson, J.; Bergeron, Y.; Bouchard, A.; Leduc, A. Beech-maple dynamics in an old-growth forest in southern Québec, Canada. Écoscience 1994, 1, 40-46.

89. Décamps, H.; Pinay, G.; Naiman, R.J.; Petts, G.E.; McClain, M.E.; Hillbricht-Ilkowska, A.; Hanley, T.A.; Holmes, R.M.; Quinn, J.; Gilbert, J.; et al. Riparian zone: Where biogeochemistry meets biodiversity in management practice. Policy J. Ecol. 2004, 52, 3-18.

90. Pollock, M.M.; Beechie, T.J. Does riparian forest restoration thinning enhance biodiversity? The ecological importance of large wood. JAWRA 2014, 50, 543-559.

91. MDDELCC. Liste des Plantes Vasculaires Vulnérables; Ministère du Développement Durable, de l'Environnement et de la Lutte aux Changements Climatiques du Québec: Québec, QC, Canada, $2014 ;$ p. 1.

92. Nault, A.; Gagnon, D. Ramet demography of Allium tricoccum, a spring ephemeral, perennial forest herb. J. Ecol. 1993, 81, 101-119.

93. Mazurek, M.J.; Zielinski, W.J. Individual legacy trees influence vertebrate wildlife diversity in commercial forests. For. Ecol. Manag. 2004, 193, 321-334.

94. Remm, J.; Lõhmus, A. Tree cavities in forests - The broad distribution pattern of a keystone structure for biodiversity. For. Ecol. Manag. 2011, 262, 579-585.

95. Gauthier, S.; Vaillancourt, M.-A.; Leduc, A.; de Grandpré, L.; Kneeshaw, D.D.; Morin, H.; Drapeau, P.; Bergeron, Y. Aménagement Écosystémique en Forêt Boréale; Presses de l'Université du Québec: Québec, QC, Canada, 2008; p. 568. 
96. Hunter, M.L. Natural fire regimes as spatial models for managing boreal forests. Biol. Conserv. 1993, 65, 115-120.

97. MacKay, D. Un Patrimoine en Péril-La Crise des Forêts Canadiennes; Les Publications du Québec: Québec, QC, Canada, 1986.

98. Kasson, M.T.; Livingston, W.H. Relationships among beech bark disease, climate, radial growth response and mortality of American beech in northern Maine, USA. For. Pathol. 2012, 42, 199-212.

99. Crow, T.R. Reproductive mode and mechanisms for self-replacement of northern red oak (Quercus rubra)—A review. For. Sci. 1988, 34, 19-40.

100. Farrar, J.L. Les Arbres du Canada. Fides et le Service Canadien des Forêts, Ressources Naturelles Canada: St-Laurent, QC, Canada, 2006; p. 502.

101. Ostry, M.E.; Laflamme, G.; Katovich, S.A. Silvicultural approaches for management of eastern white pine to minimize impacts of damaging agents. For. Pathol. 2010, 40, 332-346.

102. Anagnostakis, S.L. Chestnut Blight: The Classical Problem of an Introduced Pathogen. Mycologia 1987, 79, 23-37.

103. Diskin, M.; Steiner, K.C.; Hebard, F.V. Recovery of American chestnut characteristics following hybridization and backcross breeding to restore blight-ravaged Castanea dentata. For. Ecol. Manag. 2006, 223, 439-447.

104. Jacobs, D.F. Toward development of silvical strategies for forest restoration of American chestnut (Castanea dentata) using blight-resistant hybrids. Biol. Conserv. 2007, 137, 497-506.

105. Clark, S.; McNab, H.; Loftis, D.; Zarnoch, S. American Chestnut Growth and Survival Five Years after Planting in Two Silvicultural Treatments in the Southern Appalachians, USA. Forests 2012, $3,1017-1033$.

106. Larouche, C.; Ruel, J.-C. Development of northern white-cedar regeneration following partial cutting, with and without deer browsing. Forests 2015, 6, 344-359.

107. Côté, S.D.; Rooney, T.P.; Tremblay, J.-P.; Dussault, C.; Waller, D.M. Ecological impacts of deer overabundance. Ann. Rev. Ecol. Evol. Syst. 2004, 35, 113-147.

108. Stanturf, J.A.; Palik, B.J.; Dumroese, R.K. Contemporary forest restoration: A review emphasizing function. For. Ecol. Manag. 2014, 331, 292-323.

109. Coates, K.D.; Burton, P.J. A gap-based approach for development of silvicultural systems to address ecosystem management objectives. For. Ecol. Manag. 1997, 99, 337-354.

110. Messier, C.; Bigué, B.; Bernier, L. Using fast-growing plantations to promote forest ecosystem protection in Canada. Unasylva 2003, 54, 59-63.

111. Fortier, J.; Truax, B.; Gagnon, D.; Lambert, F. Hybrid poplar yields in Québec: Implications for a sustainable forest zoning management system. For. Chron. 2012, 88, 391-407.

112. Czapowskyj, M.M.; Safford, L.O. Site preparation, fertilization, and 10-year yields of hybrid poplar on a clearcut forest site in eastern Maine, USA. New For. 1993, 7, 331-344.

113. Gelhaye, D.; Ranger, J.; Bonneau, M. Biomass and nutrient content of a short rotation coppice of Beaupre poplars planted on a non-alluvial acidic soil improved by fertilization. Ann. For. Sci. 1997, 54, 649-665. 
114. Nelson, A.S.; Saunders, M.R.; Wagner, R.G.; Weiskittel, A.R. Early stand production of hybrid poplar and white spruce in mixed and monospecific plantations in eastern Maine. New For. 2012, 43, 519-534.

115. Christersson, L. Wood production potential in poplar plantations in Sweden. Biomass Bioenergy 2010, 34, 1289-1299.

116. Christersson, L. Poplar plantations for paper and energy in the south of Sweden. Biomass Bioenergy 2008, 32, 997-1000.

117. Hartley, M.J. Rationale and methods for conserving biodiversity in plantation forests. For. Ecol. Manag. 2002, 155, 81-95.

118. Thompson, I.D.; Baker, J.A.; Ter-Mikaelian, M. A review of the long-term effects of post-harvest silviculture on vertebrate wildlife, and predictive models, with an emphasis on boreal forests in Ontario, Canada. For. Ecol. Manag. 2003, 177, 441-469.

119. Jandl, R.; Lindner, M.; Vesterdal, L.; Bauwens, B.; Baritz, R.; Hagedorn, F.; Johnson, D.W.; Minkkinen, K.; Byrne, K.A. How strongly can forest management influence soil carbon sequestration? Geoderma 2007, 137, 253-268.

120. Laudon, H.; Sponseller, R.; Lucas, R.; Futter, M.; Egnell, G.; Bishop, K.; Ågren, A.; Ring, E.; Högberg, P. Consequences of more intensive forestry for the sustainable management of forest soils and waters. Forests 2011, 2, 243-260.

121. Ministère des Forêts, de la Faune et des Parcs. Entente d'Attribution de Biomasse Forestière (EABF) et Permis pour la Récolte de bois aux fins d'Approvisionner une Usine de Transformation du bois (PRAU); Ministère des Forêts, de la Faune et des Parcs, Gouvernement du Québec: Québec, QC, Canada, 2015.

122. Achat, D.L.; Deleuze, C.; Landmann, G.; Pousse, N.; Ranger, J.; Augusto, L. Quantifying consequences of removing harvesting residues on forest soils and tree growth-A meta-analysis. For. Ecol. Manag. 2015, 348, 124-141.

123. Hesselink, T.P. Increasing pressures to use forest biomass: A conservation viewpoint. For. Chron. 2010, 86, 28-35.

124. Fortier, J.; Gagnon, D.; Truax, B.; Lambert, F. Biomass and volume yield after 6 years in multiclonal hybrid poplar riparian buffer strips. Biomass Bioenergy 2010, 34, 1028-1040.

125. Fortier, J.; Gagnon, D.; Truax, B.; Lambert, F. Nutrient accumulation and carbon sequestration in 6 year-old hybrid poplars in multiclonal agricultural riparian buffer strips. Agric. Ecosyst. Environ. 2010, 137, 276-287.

126. Simavi, M.A. Effet de Plantations de Bandes Riveraines D'arbres sur L'abondance et la Répartition de la Faune Aquatique dans des Ruisseaux Dégradés de Milieux Agricoles dans les Cantons-de-l'Est. Master's Thesis, Université du Québec à Montréal, Montréal, QC, Canada, 2012.

127. Périnet, P.; Gagnon, H.; Morin, S. Liste des Clones Recommandés de Peuplier Hybride par Sous-Région Écologique au Québec (Mise à Jour Octobre 2010); Direction de la Recherche Forestière, MRN: Québec, QC, Canada, 2010; p. 1.

128. Woodfin, S.L.; Wright, L.L.; Curtin, D.T. In SRIC: Integration of Production and Harvesting System Costs. Proceedings of the IEA/BA Task II Workshop: Economic Evaluation of Short-Rotation Biomass Energy Systems, Duluth, MN, USA, 11-13 August 1987; Lothner, D.C., Bradley, D.P., Gambles, R.L., Eds.; USDA Forest Service: Duluth, MN, USA, 1988; pp. 115-150. 
129. McKendry, P. Energy production from biomass (part 1): Overview of biomass. Bioresour. Technol. 2002, 83, 37-46.

130. Gladstone, W.T.; Thomas Ledig, F. Reducing pressure on natural forests through high-yield forestry. For. Ecol. Manag. 1990, 35, 69-78.

131. Simončič, T.; Spies, T.; Deal, R.; Bončina, A. A conceptual framework for characterizing forest areas with high societal values: Experiences from the Pacific Northwest of USA and Central Europe. Environ. Manag. 2015, 56, 127-143.

132. Boothroyd-Roberts, K.; Gagnon, D.; Truax, B. Can hybrid poplar plantations accelerate the restoration of forest understory attributes on abandoned fields? For. Ecol. Manag. 2013, 287, 77-89.

133. Weih, M.; Karacic, A.; Munkert, H.; Verwijst, T.; Diekmann, M. Influence of young poplar stands on floristic diversity in agricultural landscapes (Sweden). Basic Appl. Ecol. 2003, 4, 149-156.

134. Brockerhoff, E.; Jactel, H.; Parrotta, J.; Quine, C.; Sayer, J. Plantation forests and biodiversity: Oxymoron or opportunity? Biodivers. Conserv. 2008, 17, 925-951.

135. Knapp, B.; Insam, H. Recycling of biomass ashes: Current technologies and future research needs. In Recycling of Biomass Ashes; Insam, H., Knapp, B.A., Eds.; Springer Berlin: Heidelberg, Germany, 2011; pp. 1-16.

136. Keith, H.; Mackey, B.G.; Lindenmayer, D.B. Re-evaluation of forest biomass carbon stocks and lessons from the world's most carbon-dense forests. PNAS 2009, 106, 11635-11640.

137. Pregitzer, K.S.; Euskirchen, E.S. Carbon cycling and storage in world forests: Biome patterns related to forest age. Glob. Change Biol. 2004, 10, 2052-2077.

138. Rheinhardt, R.; Brinson, M.; Meyer, G.; Miller, K. Carbon storage of headwater riparian zones in an agricultural landscape. Carbon Balance Manag. 2012, 7, 1-5.

139. Davies, O.; Kerr, G. Comparing the costs and revenues of transformation to continuous cover forestry for sitka spruce in Great Britain. Forests 2015, 6, 2424-2449.

140. Agence de mise en valeur de la forêt privée de l'Estrie. Liste des activités de mise en valeur admissibles à une aide financière. Available online: http://www.agenceestrie.qc.ca/ programme.htm (accessed on 25 August 2015).

141. MAPAQ. Prime-Vert—Volet 1. Interventions en agroenvironnement par une exploitation agricole. Available online: http://www.mapaq.gouv.qc.ca/fr/Productions/md/programmesliste/ agroenvironnement/sous-volet/Pages/PrimeVertvolet1.aspx (accessed on 25 August 2015).

142. Gouvernement du Québec. La Conservation au Volontaire: Vous Pouvez Faire une Différence. Principales Options de Conservation Légales pour les Propriétaires de Terrains Privés; Gouvernement du Québec: Québec, QC, Canada, 2014; p. 11.

143. Vose, J.M.; Wear, D.N.; Mayfield Iii, A.E.; Dana Nelson, C. Hemlock woolly adelgid in the southern Appalachians: Control strategies, ecological impacts, and potential management responses. For. Ecol. Manag. 2013, 291, 209-219.

144. Goldman, R.L.; Thompson, B.H.; Daily, G.C. Institutional incentives for managing the landscape: Inducing cooperation for the production of ecosystem services. Ecol. Econ. 2007, 64, 333-343.

145. Leitch, Z.J.; Lhotka, J.M.; Stainback, G.A.; Stringer, J.W. Private landowner intent to supply woody feedstock for bioenergy production. Biomass Bioenergy 2013, 56, 127-136.

146. Tittler, R.; Filotas, É.; Kroese, J.; Messier, C. Maximizing conservation and production with intensive forest management: It's all about location. Environ. Manag. 2015, 1-14. 
147. Lautenschlager, R.A. Can intensive silviculture contribute to sustainable forest management in northern ecosystems? For. Chron. 2000, 76, 283-295.

148. Bureau du forestier en chef. Succès des Plantations. Avis du Forestier en Chef. FEC-AVIS-04-2015; Bureau du forestier en chef: Roberval, QC, Canada, 2015; p. 22.

149. Dancause, A. Le Reboisement au Québec; Les Publications du Québec: Québec, QC, Canada, 2008; p. 177.

150. Labrecque, M.; Teodorescu, T.I. Field performance and biomass production of 12 willow and poplar clones in short-rotation coppice in southern Quebec (Canada). Biomass Bioenergy 2005, 29, $1-9$.

151. Bentrup, G. Conservation Buffers: Design Guidelines for Buffers, Corridors, and Greenways; Department of Agriculture, Forest Service, Southern Research Station: Asheville, NC, USA, 2008; p. 110.

152. McKinley, D.C.; Ryan, M.G.; Birdsey, R.A.; Giardina, C.P.; Harmon, M.E.; Heath, L.S.; Houghton, R.A.; Jackson, R.B.; Morrison, J.F.; Murray, B.C.; et al. A synthesis of current knowledge on forests and carbon storage in the United States. Ecol. Appl. 2011, 21, 1902-1924.

153. Schwartz, M.W. Choosing the appropriate scale of reserves for conservation. Ann. Rev. Ecol. Syst. 1999, 30, 83-108.

154. Humphrey, J.; Watts, K.; Fuentes-Montemayor, E.; Macgregor, N.; Peace, A.; Park, K. What can studies of woodland fragmentation and creation tell us about ecological networks? A literature review and synthesis. Landsc. Ecol. 2015, 30, 21-50.

155. Ma, Z.; Kittredge, D.B. How family forest owners consider timber harvesting, land sale, and conservation easement decisions: Insights from Massachusetts, USA. Int. J. For. Res. 2011, doi:10.1155/2011/290353.

156. Côté, M.-A.; Gilbert, D.; Nadeau, S. Characterizing the profiles, motivations and behaviour of Quebec's forest owners. For. Policy Econ. 2015, 59, 83-90.

157. Boothroyd-Roberts, K.; Gagnon, D.; Truax, B. Hybrid poplar plantations are suitable habitat for reintroduced forest herbs with conservation status. SpringerPlus 2013, 2, 1-13.

158. Lust, N.; Kongs, T.; Nachtergale, L.; De Keersmaeker, L. Spontaneous ingrowth of tree species in poplar plantations in Flanders. Ann. For. Sci. 2001, 58, 861-868.

159. Perron, J.-Y. Inventaire forestier. In Manuel de Foresterie; Ordre des Ingénieurs Forestiers du Québec, Ed.; Les Presses de l’Université Laval: Ste-Foy, QC, Canada, 1996; pp. 390-473.

(C) 2015 by the authors; licensee MDPI, Basel, Switzerland. This article is an open access article distributed under the terms and conditions of the Creative Commons Attribution license (http://creativecommons.org/licenses/by/4.0/). 